\title{
ANALISIS FAKTOR-FAKTOR YANG MEMENGARUHI TINGKAT KUNJUNGAN IBU DENGAN ANAK BALITA KE POSYANDU DALAM KEGIATAN PENIMBANGAN DI WILAYAH KERJA PUSKESMAS SURADITA KECAMATAN CISAUK KABUPATEN TANGERANG PROPINSI BANTEN TAHUN 2016
}

\author{
WAHIDIN \\ Fakultas Ilmu Kesehatan \\ Universitas Muhammadiyah Tangerang \\ Email: didin.wahidin1977@gmail.com
}

\begin{abstract}
ABSTRAK
Keberadaan Posyandu perlu direfitalisasi kembali sedemikian rupa. Keberadaan Posyandu mampu memberikan pelayanan dan pemantauan kesehatan secara terpadu dan komprehensif di tingkat komunitas. Konsistensi Kehadiran ibu ke Posyandu setiap bulannya dapat memaksimalkan kondisi kesehatan ibu dan anak.

Penelitian Dilakukan Untuk Menggali Dan Mengetahui Faktor-Faktor Yang Berhubungan dan memengaruhi Tingkat Kunjungan Ibu Dengan Anak Balita Ke Posyandu Dalam Kegiatan Penimbangan.

Kegiatan penelitian dilakukan dengan pendekatan cross sectional pengembangan kearah tipe deskriptif analitik yang bersipat mixed methode riset antara pendekatan kuantitatif dan kualitatif.

Hasil analisis menunjukan bahwa kunjungan ibu balita ke posyandu di Wilayah Kerja PKM Suradita relative sudah tinggi.Tidak semua faktor yang diduga berkaitan terbukti secara signifikan berhubungan dengan Kunjungan ibu dalam penimbangan balita ke posyandu.

Tingkat Kunjungan Ibu dalam Penimbangan Balita ke Posyandu dipengaruhi secara dominan oleh adanya Dukungan Keluarga, 0.498/49.8\%,Sikap Ibu 0.302/30.2\%,Jumlah tanggungan 0.190/19.0\% ,dan Pekerjaan ibu 0.156/15.6\%.
\end{abstract}

Keywords : Faktor-faktor, Tingkat Kunjungan Ibu, Kegiatan penimbangan Posyandu.

\section{PENDAHULUAN}

Keberadaan Posyandu perlu untuk terus direfitalisasi kembali sedemikian rupa karena lembaga ini merupakan perpanjangan tangan terdepan dari Puskesmas. Keberadaan Pos Pelayanan Terpadu atau Posyandu mampu memberikan pelayanan dan pemantauan kesehatan yang dilaksanakan secara terpadu dan komprehensif di tingkat komunitas.
Peran serta masyarakat dalam Posyandu khususnya dalam penimbangan Balita menjadi sangat penting khususnya dalam upaya deteksi dini kasus gizi kurang dan gizi buruk, dengan rajin menimbang balita akan terjadi pemantauan pertumbuhan balita secara intensif.Penanganan yang cepat dan tepat sesuai tatalaksana yang ditentukan akan mengurangi resiko kematian sehingga angka kematian akibat gizi buruk atau penyakit tertentu dapat ditekan sedemikian rupa. 
Masalah gizi sampai dengan saat ini masih merupakan salah satu masalah kesehatan masyarakat yang cukup serius di Indonesia. Dalam artian bahwa masalah Kekurangan gizi dan atau gizi lebih sampai dengan saat ini masih belum dapat diselesaikan secara optimal, Pada Tahun 2005 terdapat sekitar 5 juta balita mengalami gizi kurang dan diperkirakan masih terdapat sekitar 1,7 juta balita diantaranya menderita gizi buruk yang keberadaannya tersebar di Indonesia,prevalensi masalah gizi lebih (obesitas) mulai meningkat khususnya pada kelompok sosial ekonomi menengah ke atas di perkotaan. Dengan kata lain, saat ini Indonesia menghadapi masalah gizi ganda yang tentunya kondisi-kondisi ini sangat merisaukan sekaligus mengkhawatirkan karena dapat mengancam kualitas Sumber Daya Manusia (SDM) yang sangat diperlukan di masa mendatang (Depkes RI, 2007).

Depkes RI (2007) mengungkapkan bahwa Badan Kesehatan Dunia untuk anakanak United Nations Children's Fund (UNICEF) merilis laporan bahwa Indonesia menduduki peringkat kelima dunia untuk negara dengan jumlah anak yang terhambat pertumbuhannya paling besar dengan perkiraan sebanyak 7,7 juta balita, sejalan dengan Hasil penelitian Riskesdas tahun 2010 yang mengemukakan bahwa prevalensi gizi buruk pada anak balita adalah sebesar $4,9 \%$, dan gizi kurang $13 \%$, hal ini dapat diminimalkan bila ibu membawa anak balita ke posyandu data lanjutan dikemukakan bahwa pada tahun 2010, diperkirakan sekitar 91,3\% bayi usia $6-11$ bulan dan $74,5 \%$ anak balita dibawa ke posyandu hanya satu kali dalam 6 bulan terakhir (Kemenkes RI,2011).

Masih menurut Depkes RI (2007), Upaya penanggulangan gizi kurang dan gizi buruk sudah seharusnya dapat mengedepankan upaya-upaya promosi dan pencegahan artinya mengupayakan anak yang sehat agar tetap sehat, jika kegiatan ini dapat dilakukan setiap anak ditimbang di posyandu, berat badannya diplot didalam
KMS terdata sedemikian rupa maka akan dengan mudah ibu dan kader mengetahui jika terjadi gangguan pertumbuhan anak sedini mungkin sebelum anak jatuh pada kondisi gizi kurang atau buruk. Ibu yang tidak menimbang balitanya ke posyandu dapat menyebabkan tidak terpantaunya pertumbuhan dan perkembangan balita dan berturut-turut berisiko keadaan gizinya memburuk sehingga mengalami gangguan pertumbuhan (Depkes RI, 2006).

Berbagai penelitian telah membuktikan ada hubungan yang sangat erat antara kematian bayi dan balita dengan kekurangan gizi. Keadaan gizi yang buruk akan menurunkan daya tahan anak sehingga anak mudah sakit hingga bisa berakibat pada kematian. Badan Kesehatan Dunia WHO memperkirakan bahwa 54\% kematian bayi dan anak balita dilatarbelakangi keadaan gizi yang buruk.

Maka dari itu Kegiatan posyandu sangat penting untuk terus dikembangkan guna mendorong kemandirian masyarakat agar dapat berperilaku hidup bersih dan sehat. Penyelenggaraan posyandu dilakukan oleh kader yang telah dilatih dibidang kesehatan dan secara teknis oleh petugas kesehatan. Pada Tahun 2005 terdapat sekitar 5 juta balita mengalami gizi kurang diperkirakan masih terdapat sekitar 1,7 juta balita diantaranya menderita gizi buruk yang keberadaannya tersebar di Indonesia. Kementrian Kesehatan memprioritaskan untuk selalu meningkatkan fungsi dan kinerja posyandu, utamanya untuk meningkatkan cakupan pemantauan pertumbuhan anak (Kemenkes RI, 2007).

Sumber daya manusia yang sehat dan berkualitas merupakan modal utama atau investasi dalam pembangunan kesehatan. Ukuran kualitas SDM dapat dilihat pada Indeks Pembangunan Manusia (IPM), sedangkan ukuran kesejahteraan masyarakat antara lain dapat dilihat pada tingkat kemiskinan dan status gizi masyarakat (Depkes RI, 2007).

Memang secara kuantitas, perkembangan jumlah posyandu mengalami perkembangan yang cukup 
pesat dan menggembirakan karena saat ini jika dirata-ratakan di setiap desa ditemukan sekitar 3 sampai 4 Posyandu. Pada saat Posyandu dicanangkan, tercatat sebanyak 25.000 Posyandu, tahun 2004 sebanyak 238.699 Posyandu, dan tahun 2011 meningkat menjadi 268.439 Posyandu. Namun, bila ditinjau dari aspek kualitas, masih ditemukan banyak masalah antara lain misalnya saja kelengkapan sarana dan ketrampilan kader yang belum memadai (Depkes RI, 2011).

Ibu yang tidak menimbang balitanya ke posyandu dapat menyebabkan tidak terpantaunya pertumbuhan dan perkembangan balita dan berturut-turut berisiko keadaan gizinya memburuk sehingga dapat mengalami gangguan pertumbuhan (Depkes RI, 2006).

Data Cakupan penimbangan balita di Kabupaten Tangerang dalam Profil Kesehatan Kesehatan Kabupaten Tangerang Tahun 2010, 2014 dan tahun 2015 bergerak fluktuatif namun kondisinya rata-rata sudah diatas capaian $70 \%$ hal ini dapat dikaji dari table-tabel berikut ini:

Tabel 1. Cakupan Penimbangan Balita di Wilayah Kerja Puskesmas Suradita Kecamatan Cisauk Kabupaten Tangerang Tahun 2010

\begin{tabular}{|c|l|c|c|c|c|c|c|}
\hline No & Puskesmas & $\begin{array}{c}\text { Balita } \\
\text { Yang } \\
\text { Ada }\end{array}$ & $\begin{array}{c}\text { Balita } \\
\text { Ditimbang }\end{array}$ & $\begin{array}{c}\text { Cakupan } \\
\text { Penimbangan } \\
\text { Balita }\end{array}$ & $\begin{array}{c}\text { Berat Badan } \\
\text { Bawah } \\
\text { Garis } \\
\text { Merah }\end{array}$ & $\begin{array}{c}\text { \% } \\
\text { D/S }\end{array}$ & $\begin{array}{c}\text { \% } \\
\text { BGM }\end{array}$ \\
\hline 1 & Cisauk & 2253 & 1575 & - & 92 & 69.91 & 5.84 \\
\hline $\mathbf{2}$ & Suradita & $\mathbf{2 7 7 6}$ & $\mathbf{2 6 4 0}$ & $\mathbf{2 3 3 7}$ & $\mathbf{8 3}$ & $\mathbf{9 5 . 1 0}$ & $\mathbf{3 . 1 4}$ \\
\hline 3 & Sukamulya & 5692 & 3574 & 3388 & 177 & 62.79 & 4.95 \\
\hline
\end{tabular}

Sumber : Profil Kesehatan Kabupaten Tangerang 2010

Tabel 2. Cakupan Penimbangan Balita di Wilayah Kerja Puskesmas Suradita Kecamatan Cisauk Kabupaten Tangerang Tahun 2014

\begin{tabular}{|c|l|c|c|c|c|c|}
\hline No & Puskesmas & $\begin{array}{c}\text { Balita } \\
\text { Yang } \\
\text { Ada }\end{array}$ & $\begin{array}{c}\text { Balita } \\
\text { Ditimbang }\end{array}$ & $\begin{array}{c}\text { Berat Badan } \\
\text { Bawah } \\
\text { Garis } \\
\text { Merah }\end{array}$ & $\begin{array}{c}\text { \% } \\
\text { D/S }\end{array}$ & $\begin{array}{c}\text { \% } \\
\text { BGM }\end{array}$ \\
\hline 1 & Cisauk & 2998 & 2128 & 41 & 71.0 & 1.9 \\
\hline $\mathbf{2}$ & Suradita & $\mathbf{4 9 8 9}$ & $\mathbf{2 4 1 2}$ & $\mathbf{3 8}$ & $\mathbf{4 8 . 3}$ & $\mathbf{1 . 6}$ \\
\hline 3 & Sukamulya & 4844 & 4809 & 69 & 99.3 & 1.4 \\
\hline
\end{tabular}

Sumber : Profil Kesehatan Kabupaten Tangerang 2014

Tabel 3. Cakupan Penimbangan Balita di Wilayah Kerja Puskesmas Suradita Kecamatan Cisauk Kabupaten Tangerang Tahun 2015

\begin{tabular}{clccccc}
\hline No & Puskesmas & $\begin{array}{c}\text { Balita } \\
\text { Yang } \\
\text { Ada }\end{array}$ & $\begin{array}{c}\text { Balita } \\
\text { Ditimbang }\end{array}$ & $\begin{array}{c}\text { Berat Badan } \\
\text { Bawah } \\
\text { Garis } \\
\text { Merah }\end{array}$ & $\begin{array}{c}\text { \% } \\
\text { D/S }\end{array}$ & $\begin{array}{c}\text { \% } \\
\text { BGM }\end{array}$ \\
\hline 1 & Cisauk & 2297 & 2295 & 490 & 99.9 & 22.9 \\
\hline $\mathbf{2}$ & Suradita & $\mathbf{4 5 1 6}$ & $\mathbf{3 6 1 1}$ & $\mathbf{9 7 2}$ & $\mathbf{8 0}$ & $\mathbf{1 4 . 6}$ \\
\hline 3 & Sukamulya & 6617 & 6253 & 1472 & 94.5 & 8.5 \\
\hline
\end{tabular}

Sumber : Profil Kesehatan Kabupaten Tangerang 2015 
Berdasarkan Peraturan Menteri Kesehatan Nomor 741 Tahun 2008 Tentang Standard Pelayanan Minimal (SPM) Kesehatan Kabupaten/Kota, cakupan pelayanan anak balita yaitu harus sudah mencapai 90\%, pada Tahun 2016 ini Puskesmas Suradita Kecamatan Cisauk Kabupaten Tangerang menargetkan cakupan penimbangan balita dapat mencapai angka diatas 90\%. Berdasarkan Profil Kesehatan Kabupaten Tangerang Tahun 2010,2014 dan 2015 diketahui bahwa Puskesmas Suradita Kecamatan Cisauk pernah mencapai angka capaian 95\% dengan BGM sebesar $3.14 \%$ pada tahun 2010, data Tahun 2014 menurun menjadi $48.3 \%$ dan BGM sebesar $1.6 \%$ dan pada tahun 2015 cakupan penimbangan balita naik lagi dan mencapai $80 \%$ namun BGM meningkat menjadi $14.6 \%$ dari tahun sebelumnya.

Sejalan dengan hasil survei pendahuluan yang dilakukan melalui kegiatan wawancara kepada salah seorang petugas Puskesmas yang juga sering bertugas di Posyandu dan beberapa orang kader dapat sedikit diketahui gambaran bahwa :

1. Tingkat kesadaran masyarakat di Wilayah Kerja Puskesmas Suradita Kecamatan Cisauk Kabupaten Tangerang dalam melakukan kegiatan Posyandu khususnya membawa balitanya untuk melakukan penimbangan masih berjalan kurang optimal dan berfluktuatif sehingga Puskesmas sedikit mengalami kesulitan dalam upayanya mendata jumlah balita yang sebenarnya dan mencapai target minimal yang sudah ditentukan pemerintah.

2. Dalam kasus selanjutnya ada kecenderungan bahwa sebagian besar ibu bayi/balita hanya membawa anaknya ke posyandu sampai imunisasi dasar lengkap saja dan menimbang anaknya hingga usia tiga tahun, jika imunisasi dasar lengkap sudah dilakukan dan melakukan penimbangan maka setelah usia anaknya lebih dari dua tahun ada kecenderungan mereka tidak datang lagi membawa anaknya ke posyandu.

3. Laporan cakupan penimbangan di posyandu yang ditemukan di Puskesmas Suradita adalah laporan cakupan penimbangan bayi hingga usia dibawah dua tahun (baduta) dan ada laporan cakupan penimbangan bayi hingga usia Balita, keadaan ini menunjukkan pertumbuhan anak balita sebenarnya sudah cukup terpantau namun kondisinya masih berpluktuatif dan belum mencapai target yang sudah ditentukan, maka dari itu petugas puskesmas dan para kader kesehatan yang ada untuk tidak bosan mengingatkan ibu bayi/balita pada saat pelaksanaan posyandu untuk rutin memantau pertumbuhan anaknya ke posyandu hingga usia lima tahun dan mengajak kembali ibu yang lainnya untuk datang dan menggunakan Posyandu yang ada.

Berdasarkan uraian latar belakang di atas dan hasil studi awal yang dilakukan melalui survey pendahuluan, dapat dirumuskan masalah penelitian adalah belum optimal dan tercapainya cakupan minimal penimbangan balita ke posyandu di Wilayah Kerja Puskesmas Suradita Kecamatan Cisauk Kabupaten Tangerang Propinsi Banten Tahun 2016 kondisi ini menggambarkan bahwa tinggkat kunjungan ibu balita masih belum berjalan secara optimal atas dasar itulah peneliti merasa tertarik untuk meneliti Faktorfaktor apa saja yang berhubungan dan memengaruhi tingkat kunjungan ibu dalam penimbangan balita ke posyandu di wilayah kerja puskesmas Suradita Kecamatan Cisauk Kabupaten Tangerang.

Tujuan penelitian tiada lain adalah untuk mengetahui Faktor-faktor yang berhubungan dan memengaruhi tingkat kunjungan ibu dalam penimbangan balita ke posyandu di Wilayah Kerja Puskesmas Suradita Kecamatan Cisauk Kabupaten Tangerang Tahun 2016. Adapun

Manfaat Penelitian ini adalah sebagai berikut : 
1. Menggali Faktor-faktor yang berhubungan dan memengaruhi tingkat kunjungan ibu yang memiliki balita sehingga diketahui factor apa saja yang dominan atau signifikan memengaruhinya sehingga ibu yang memiliki anak balita kerasan untuk selalu menggunakan posyandu..

2. Bahan Masukan kepada Puskesmas Suradita dalam rangka meningkatkan cakupan penimbangan balita sehingga cakupan persyaratan minimal dapat terpenuhi dan semoga menjadi Sumbangan pemikiran kepada Puskesmas Suradita dalam rangka peningkatan upaya menyusun strategi pembinaan yang efektif dan efisien terhadap posyandu, inovatif dan menarik perhatian masyarakat di Wilayah Kerjanya.

3. Sebagai bahan masukan kepada Dinas Kesehatan Kabupaten Tangerang dalam rangka pembinaan Posyandu dan upaya peningkatan cakupan penimbangan.

\section{METODE PENELITIAN}

Jenis penelitian yang digunakan dalam penelitian ini adalah deskriptif analitik dengan pendekatan desain cross sectional yaitu untuk mempelajari adanya hubungan atau pengaruh antara faktor Umur, pendidikan, pekerjaan, penghasilan,paritas,pengetahuan, sikap ibu, kehadiran kader posyandu, kelengkapan peralatan posyandu,jarak posyandu, sikap atau dukungan kader, dan sikap atau dukungan keluarga dengan tingkat Kunjungan ibu dalam penimbangan balita ke posyandu di Wilayah Kerja Puskesmas Suradita Kecamatan Cisauk Kabupaten Tangerang Tahun 2016. Kegiatan penelitian dilakukan melalui Pendekatan cross sectional ini dilakukan untuk mengkaji beberapa Faktor risiko dan efek diobservasi sekaligus pada saat yang sama.

Lokasi Penelitian ini dilakukan di Posyandu yang menjadi Wilayah Kerja Puskesmas Suradita Kecamatan Cisauk Kabupaten Tangerang Tahun 2016.
Populasi pada penelitian ini adalah semua ibu yang mempunyai balita yang berusia antara 24 sampai dengan 60 bulan yang mengikuti kegiatan penimbangan balita ke posyandu di Wilayah Kerja Puskesmas Suradita Kecamatan Cisauk Kabupaten Tangerang Tahun 2016.

Berdasarkan perhitungan besar sampel, maka besar sampel minimal yang dibutuhkan ditentukan jumlahnya sebanyak 85 orang responden. Teknik pengambilan sampel dilakukan dengan metode simple random sampling yaitu dengan mengumpulkan seluruh daftar nama populasi ibu yang mempunyai balita usia antara 24 sampai dengan 60 bulan yang menimbangkan balitanya ke posyandu di Wilayah Kerja Puskesmas Suradita Kecamatan Cisauk Kabupaten Tangerang Tahun 2016.

Berdasarkan data yang sudah ada peneliti melakukan kunjungan ke beberapa posyandu untuk mendata responden dengan menggunakan kuesioner sejumlah yang sudah ditentukan yaitu sebanyak 85 orang responden. Metode Pengumpulan Data dilakukan sebagai berikut :

1. Data primer diperoleh dari wawancara langsung dengan responden yang berpedoman pada kuesioner penelitian.

2. Data sekunder diperoleh dengan cara melihat catatan kader yang berhubungan dengan penelitian, Profil Puskesmas Suradita, Profil Dinas Kesehatan Kabupaten Tangerang Tahun 2010,2014 dan 2015 dan beberapa penelitian dari beberapa jurnal yang ada.

3. Analisis data dilakukan secara bertahap, yaitu dengan analisis univariat dan kemudian dilanjutkan dengan analisis bivariat. Analisis multivariat dimungkinkan dilakukan setelah analisis univariat dan bevariat selesai dilakukan.

Data primer yang sudah diperoleh melalui kuesioner diolah dan ditabulasi dengan menggunakan analisis statistik Uji Chi Square $\left(\mathrm{X}^{2}\right)$, pada tingkat kemaknaan 95\% $(\alpha 0,05)$ dan Uji Korelasi Product 
Moment dengan tingkat kemaknaan alpha $(\alpha)=0,05$ pengolahan data primer dibantu dengan menggunakan komputer program Excell dan SPSS ver.23.

\section{HASIL DAN PEMBAHASAN.}

1. Analisis Univariat.
Analisis Univariat berupaya untuk dapat menjelaskan atau mendeskripsikan karateristik variabel yang menjadi indevenden variabel maupun dependent variabel. Gambaran Karakteristis Responden dan Variabel penelitian tersebut dapat dianalisa dan dikaji pada table-tabel seperti berikut ini:

Tabel 4. Distribusi Responden Menurut Keikutsertaan Pelatihan,status keluarga,Jumlah Tanggungan,suku bangsa,agama di Wilayah Kerja Puskesmas Suradita Kecamatan Cisauk Kabupaten Tangerang Propinsi Banten Tahun 2016.

\begin{tabular}{|c|c|c|}
\hline Variabel & $\begin{array}{c}\begin{array}{c}\text { Jumlah } \\
\mathrm{N}=85\end{array} \\
\end{array}$ & $\%$ \\
\hline \multicolumn{3}{|l|}{ Keikutsertaan Pelatihan } \\
\hline a) Pernah & 35 & 41.2 \\
\hline b) Tidak Pernah mengikuti Latihan & 50 & 58.8 \\
\hline \multicolumn{3}{|l|}{ Status } \\
\hline Menikah & 65 & 76.5 \\
\hline b) Janda & 20 & 23.5 \\
\hline \multicolumn{3}{|l|}{ Jumlah Tanggungan } \\
\hline$\leq 4$ Orang & 70 & 82.4 \\
\hline$\geq 4$ Tahun & 15 & 17.6 \\
\hline \multicolumn{3}{|l|}{ Suku Bangsa } \\
\hline Batak & 9 & 10.6 \\
\hline Jawa & 41 & 48.2 \\
\hline Sunda & 30 & 35.3 \\
\hline Banjar & 2 & 2.4 \\
\hline Lainnya & 3 & 3.5 \\
\hline \multicolumn{3}{|l|}{ Agama } \\
\hline Islam & 60 & 70.6 \\
\hline Kristen & 10 & 11.8 \\
\hline Hindu & 3 & 3.5 \\
\hline Budha & 5 & 5.9 \\
\hline Lainnya & 7 & 8.2 \\
\hline \multicolumn{3}{|l|}{ Domisili Tempat Tinggal } \\
\hline a) Desa Suradita & 70 & 82.4 \\
\hline b) Luar desa Suradita & 15 & 17.6 \\
\hline
\end{tabular}

Sumber : Data Primer 2016

Dari tabel 4 diatas tergambar $41.2 \%$ ibu yang memiliki balita pernah mengikuti pelatihan pengurusan anak balita dan $58.8 \%$ tidak pernah mengikuti pelatihan. Sebanyak $76.6 \%$ status mereka berstatus menikah dan $23.5 \%$ berstatus janda.

Dari sisi jumlah tanggungan $82.4 \%$ menanggung keluarga kurang dari 4 orang dan $17.6 \%$ menanggung keluarga sebanyak lebih dari 4 orang.
Dari sisi suku bangsa $10.6 \%$ suku batak,48.2\% suku Jawa,35.3\% suku Sunda,2.4\% suku Banjar dan suku lainnya missal suku China,Madura dan sebagainya sebanyak 3.5\%. dari sisi Agama 70.6\% beragama Islam, $11,8 \%$ Beragama Kristen,3.5\% Hindu,5.9\% beragama Budha dan $8.2 \%$ beragama lainnya.

Dari sisi Domisili Pengunjung Posyandu di wilayah kerja Puskesmas Suradita $82.4 \%$ adalah merupakan 
penduduk Desa Suradita dan $17.6 \%$ responden mengaku berdomisili di luar Desa Suradita.

Tabel 5. Distribusi Responden Menurut Umur, pekerjaan, Pendidikan,penghasilan,paritas, jenis kelamin balita,usia anak,pengetahuan,sikap ibu,dukungan kader, dukungan keluarga dan tingkat kunjungan ibu ke posyandu di Wilayah Kerja Puskesmas Suradita Kecamatan Cisauk Kabupaten Tangerang Propinsi Banten Tahun 2016.

\begin{tabular}{|c|c|c|}
\hline Variabel & $\begin{array}{c}\text { Jumlah } \\
\mathrm{N}=85\end{array}$ & $\%$ \\
\hline \multicolumn{3}{|l|}{ Umur } \\
\hline a) $\leq 20$ Tahun & 5 & 5.9 \\
\hline b) $21-29$ Tahun & 53 & 62.4 \\
\hline c) 30-39 Tahun & 21 & 24.7 \\
\hline d) 40-50 Tahun & 2 & 2.4 \\
\hline e) $\geq 50$ Tahun & 4 & 4.7 \\
\hline \multicolumn{3}{|l|}{ Pekerjaan } \\
\hline a) Ibu Rumah Tangga & 52 & 61.2 \\
\hline b) Pegawai Negeri Sipil & 14 & 16.5 \\
\hline c) Pegawai Swasta & 19 & 22.4 \\
\hline \multicolumn{3}{|l|}{ Pendidikan Terakhir } \\
\hline a) Dasar & 44 & 51.8 \\
\hline b) Menengah & 25 & 29.4 \\
\hline c) Pendidikan Tinggi & 16 & 18.8 \\
\hline \multicolumn{3}{|l|}{ Penghasilan } \\
\hline a) < UMK Kabupaten Tangerang Rp3.270.936,13 & 65 & 76.5 \\
\hline b) >UMK Kabupaten Tangerang Rp 3.270.936.13 & 20 & 23.5 \\
\hline \multicolumn{3}{|l|}{ Penetapan berdasar pada PP nomor 78 tahun 2015} \\
\hline \multicolumn{3}{|l|}{ Paritas } \\
\hline a) Primipara & 15 & 17.6 \\
\hline b) Multipara & 70 & 82.4 \\
\hline \multicolumn{3}{|l|}{ Jenis Kelamin Balita } \\
\hline a) Laki - laki & 49 & 57.6 \\
\hline b) Perempuan & 36 & 42.4 \\
\hline \multicolumn{3}{|l|}{ Usia Anak } \\
\hline a) $0-12$ bulan & 5 & 5.9 \\
\hline b) $13-36$ bulan & 41 & 48.2 \\
\hline c) $37-59$ bulan & 39 & 45.9 \\
\hline \multicolumn{3}{|l|}{ Gambaran Pengetahuan Ibu tentang Posyandu } \\
\hline a) Baik & 46 & 54.1 \\
\hline b) Cukup & 23 & 27.1 \\
\hline c) Kurang & 16 & 18.8 \\
\hline \multicolumn{3}{|l|}{ Gambaran Sikap ibu pada Posyandu } \\
\hline a) Baik & 27 & 31.8 \\
\hline b) Cukup & 48 & 56.5 \\
\hline c) Kurang & 10 & 11.8 \\
\hline \multicolumn{3}{|l|}{ Gambaran Sikap dukungan Kader } \\
\hline a) Ada Dukungan & 65 & 76.5 \\
\hline b) Kurang Ada Dukungan & 15 & 17.6 \\
\hline c) Tidak Ada Dukungan & 5 & 5.9 \\
\hline $\begin{array}{l}\text { Gambaran Sikap dukungan Keluarga } \\
\text { a) Ada Dukungan }\end{array}$ & 55 & 64.7 \\
\hline
\end{tabular}




\begin{tabular}{|c|c|c|}
\hline b) Kurang Ada Dukungan & 20 & 23.5 \\
c) Tidak Ada Dukungan & 10 & 11.8 \\
\hline Tingkat Kunjungan ibu balita Ke Posyandu & 5 & 5.9 \\
a) Tidak Pernah & 10 & 11.8 \\
b) $\leq 8$ X dalam Setahun & 70 & 82.4 \\
c) $\geq 8$ X dalam Setahun & & \\
\hline Tingkat Kehadiran Kader Posyandu. & 50 & 17.6 \\
a) Tidak pernah hadir & 20 & 23.5 \\
b) Jarang Hadir & 15 & 58.8 \\
c) Selalu Hadir & 77 & \\
\hline Kelengkapan Peralatan dan sarana Posyandu & 5 & 90.6 \\
a) Kurang lengkap & 3 & 5.9 \\
b) Cukup Lengkap & & 3.5 \\
c) Sangat Lengkap & 19 & 22.4 \\
\hline Jarak rumah menuju Ke Posyandu & 15 & 17.6 \\
a) Jauh & 51 & 60.0 \\
b) Cukup Jauh & & \\
c) Sangat Dekat & & \\
\hline
\end{tabular}

\section{Sumber : Data Primer 2016}

Berdasarkan Dari Tabel 5 diatas tergambar mayoritas responden $62.4 \%$ berusia antara 21-29 tahun dan 24.7\% berusia antara 30-39 tahun. $61.2 \%$ bekerja sebagai ibu rumah tangga dengan penghasilan $76.5 \%$ masih dibawah UMK Kabupaten Tangerang, $82.4 \%$ paritas multipara,57.6\% balita yang ditimbang berjenis kelamin laki-laki,48.2\% berusia 13-36 bulan. Gambaran tingkat pengetahuan ibu tentang posyandu $54.1 \%$ tergambar sudah cukup baik,tingkat dukungan kader $76.5 \%$ kader sudah memberikan dukungan,dukungan keluarga tergambar sekitar $64.7 \%$ keluarga mendukung dan tingkat kunjungan ibu ke posyandu $82.4 \%$ dalam setahun lebih dari 8 kali.

Tingkat Kehadiran Kader posyandu $58.8 \%$ selalu hadir dalam kegiatan posyandu dan $23.5 \%$ kader posyandu jarang hadir ke kegiatan Posyandu yang diadakan. Dari sisi kelengkapan sarana dan prasarana posyandu $90.6 \%$ resonden menilai masih kurang lengkap. Dari sisi jarak, letak posyandu $60.0 \%$ sangat dekat dengan rumah penduduk.

\section{Analisis Bivariat.}

Hasil penelitian dan pengkajian tentang pengaruh dan atau hubungan antar factor yang diteliti meliputi keikutsertaan ibu dalam pelatihan,status ibu balita,jumlah tanggungan,suku bangsa,agama,domisili tempat tinggal, usia ibu, pekerjaan ibu, pendidikan ibu, penghasilan, paritas, jeniskelamin anak, usia anak, pengetahuan ibu,sikap ibu pada posyandu, dukungan kader, dukungan keluarga, kehadiran kader, kelengkapan sarana dan prasarana,jarak rumah ke posyandu dengan tingkat Kunjungan ibu dalam penimbangan balita ke posyandu di Wilayah Kerja Puskesmas Suradita Kecamatan Cisauk Kabupaten Tangerang Tahun 2016 adalah sebagai berikut : 
Tabel 6. Hubungan Tingkat Keikutsertaan Pelatihan ibu balita terhadap Tingkat kunjungan Ibu dalam Penimbangan Balita ke Posyandu di Wilayah Kerja Puskesmas

Suradita Kecamatan Cisauk Kabupaten Tangerang Propinsi Banten Tahun 2016.

\begin{tabular}{|c|c|c|c|c|c|c|c|c|c|c|}
\hline \multirow{3}{*}{$\begin{array}{c}\text { Keikutsertaan } \\
\text { Pelatihan Ibu Balita }\end{array}$} & \multicolumn{6}{|c|}{$\begin{array}{c}\text { Tingkat Kunjungan Ibu Balita ke } \\
\text { Posyandu }\end{array}$} & \multirow{2}{*}{\multicolumn{2}{|c|}{ Jumlah }} & \multirow{2}{*}{$\begin{array}{c}\text { Koefisie } \\
\text { n } \\
\text { Korella } \\
\text { si } \\
(\mathbf{r}) \\
\end{array}$} & \multirow{3}{*}{$\begin{array}{c}\text { Nilai } \\
\rho\end{array}$} \\
\hline & \multicolumn{2}{|c|}{$\begin{array}{l}\text { Tidak } \\
\text { Pernah }\end{array}$} & \multicolumn{2}{|c|}{$\begin{array}{c}\leq 8 X \\
\text { dalam } \\
\text { Setahun }\end{array}$} & \multicolumn{2}{|c|}{$\begin{array}{l}\geq 8 \text { X dalam } \\
\text { Setahun }\end{array}$} & & & & \\
\hline & $\mathbf{n}$ & $\%$ & $\mathbf{N}$ & $\%$ & $\mathbf{N}$ & $\%$ & $\mathbf{n}$ & $\%$ & & \\
\hline Pernah & 4 & 8.0 & 8 & 16.0 & 38 & 76.0 & 50 & 100 & & \\
\hline Tidak Pernah & 1 & 2.9 & 2 & 5.7 & 32 & 91.4 & 35 & 100 & 0.288 & .18 \\
\hline Total & 5 & 5.9 & 10 & 11.8 & 70 & 82.4 & 85 & 100 & & \\
\hline
\end{tabular}

Sumber : Data Primer 2016

Hasil analisis bivariat dari tabel 6 diatas menunjukkan bahwa Tingkat Kunjungan ibu antara ibu yang yang pernah mengikuti pelatihan dengan tingkat kunjungan ibu balita menunjukan bahwa sebanyak $(8,0 \%)$ tidak pernah mengunjungi Posyandu $16 \%$ mengujungi posyandu kurang dari 8 kali dalam setahun dan $76 \%$ ibu balita yang pernah mengikuti pelatihan balita mengunjungi posyandu lebih dari 8 kali dalam setahun. Begitu juga ibu yang tidak pernah ikut pelatihan $91.4 \%$ mengunjungi posyandu lebih dari 8 kali dalam setahun. Maka dari itu jika dilihat dari ibu yang pernah pelatihan dan tidak pelatihan tingkat kunjungan ke posyandu sama-sama tinggi.
Hasil uji statistik dengan Chi-Square menunjukkan bahwa nilai Probabilitas (p) $=0,185$ yang berarti $\mathrm{p}>0,05$ artinya Ho diterima, hal ini berarti tidak ada hubungan yang signifikan antara responden yang pernah ikut pelatihan dan yang tidak dengan tingkat kunjungan ibu dalam penimbangan balita ke posyandu,Nilai Korellasi didapat sebesar 0,288 menunjukan hubungan yang terjadi relative lemah dan tiada bermakna. Ini berkaitan bahwa tingkat kesadaran ibu yang pernah latihan dan yang tidak pada dasarnya sama tingginya dalam hal ini kegiatan pelatihan tidak memiliki hubungan yang bermakna.

Tabel 7. Hubungan Status ibu balita terhadap Tingkat kunjungan Ibu dalam Penimbangan Balita ke Posyandu di Wilayah Kerja Puskesmas Suradita Kecamatan Cisauk Kabupaten Tangerang Propinsi Banten Tahun 2016.

\begin{tabular}{|c|c|c|c|c|c|c|c|c|c|c|}
\hline \multirow{3}{*}{$\begin{array}{l}\text { Status Ibu } \\
\text { Balita }\end{array}$} & \multicolumn{6}{|c|}{ Tingkat Kunjungan Ibu Balita ke Posyandu } & \multirow{2}{*}{\multicolumn{2}{|c|}{ Jumlah }} & \multirow{3}{*}{\begin{tabular}{|c|} 
Koefisie \\
$\mathbf{n}$ \\
Korella \\
si \\
$(\mathbf{r})$ \\
\end{tabular}} & \multirow{3}{*}{$\begin{array}{c}\text { Nilai } \\
\rho\end{array}$} \\
\hline & \multicolumn{2}{|c|}{ Tidak Pernah } & \multicolumn{2}{|c|}{$\begin{array}{c}\leq \mathbf{8 X} \text { dalam } \\
\text { Setahun }\end{array}$} & \multicolumn{2}{|c|}{$\begin{array}{l}\geq 8 \times \text { dalam } \\
\text { Setahun }\end{array}$} & & & & \\
\hline & $\mathbf{n}$ & $\%$ & $\mathbf{n}$ & $\%$ & $\mathbf{n}$ & $\%$ & $\mathbf{n}$ & $\%$ & & \\
\hline Menikah & 2 & 10.0 & 3 & 15.0 & 15 & 75.0 & 20 & 75.0 & \multirow{3}{*}{0.117} & \multirow{3}{*}{0.560} \\
\hline Janda & 3 & 4.60 & 7 & $\mathbf{1 0 . 8}$ & 55 & 84.6 & 65 & 84.6 & & \\
\hline Total & 5 & 5.90 & 10 & $\mathbf{1 1 . 8}$ & $\mathbf{7 0}$ & 82.4 & 85 & 100 & & \\
\hline
\end{tabular}

Sumber : Data Primer 2016

Hasil uji status ibu dengan tingkat kunjungan ke posyandu dalam penimbangan balita dapat dianalisis dari tabel 7 berikut ini,ibu dengan status janda tingkat kunjungan ke posyandu ternyata lebih tinggi daripada ibu dengan status menikah, ibu menikah $78 \%$ dan ibu dengan status janda $84.6 \%$ melakukan kunjungan lebih dari 8 kali.

Hasil uji statistik dengan Chi-Square menunjukkan bahwa nilai Probabilitas (p) $=0,560$ yang berarti $\mathrm{p}>0,05$ artinya Ho 
diterima, hal ini berarti tidak ada hubungan yang signifikan antara status ibu dengan status menikah dengan ibu yang berstatus janda dalam penimbangan balita ke posyandu nilai korellasi didapat sebesar 0,117 menunjukan hubungan yang terjadi lemah dan tiada bermakna. Ini berkaitan bahwa status ibu dengan menikah dan janda pada tinggkat kunjungan sama tingginya. Mau ibu itu menikah atau janda ibu-ibu balita tingkat kehadirannya sama tinggi.

.Tabel 8. Hubungan Jumlah Tanggungan terhadap Tingkat kunjungan Ibu dalam Penimbangan Balita ke Posyandu di Wilayah Kerja Puskesmas Suradita Kecamatan Cisauk Kabupaten Tangerang Propinsi Banten Tahun 2016.

\begin{tabular}{|c|c|c|c|c|c|c|c|c|c|c|}
\hline \multirow{3}{*}{$\begin{array}{c}\text { Jumlah } \\
\text { Tanggungan } \\
\text { Ibu Balita }\end{array}$} & \multicolumn{6}{|c|}{$\begin{array}{c}\text { Tingkat Kunjungan Ibu Balita ke } \\
\text { Posyandu }\end{array}$} & & & \multirow{3}{*}{$\begin{array}{l}\text { Koefisien } \\
\text { Korellasi } \\
\quad(\mathbf{r})\end{array}$} & \multirow{3}{*}{$\begin{array}{c}\text { Nilai } \\
\rho\end{array}$} \\
\hline & \multicolumn{2}{|c|}{$\begin{array}{l}\text { Tidak } \\
\text { Pernah }\end{array}$} & \multicolumn{2}{|c|}{$\begin{array}{l}\leq \mathbf{8 X} \text { dalam } \\
\text { Setahun }\end{array}$} & \multicolumn{2}{|c|}{$\begin{array}{c}\geq 8 \mathrm{X} \\
\text { dalam } \\
\text { Setahun }\end{array}$} & \multicolumn{2}{|c|}{ Jumlah } & & \\
\hline & $\mathbf{n}$ & $\%$ & $\mathbf{n}$ & $\%$ & n & $\%$ & $\mathbf{n}$ & $\%$ & & \\
\hline$\leq 4$ Orang & 3 & 20.0 & 3 & 20.0 & 9 & 60.0 & 15 & 17.6 & & \\
\hline$\geq 4$ Orang & 2 & 2.90 & 7 & 10.0 & 61 & 87.1 & 70 & 82.4 & 0.309 & 0.016 \\
\hline Total & 5 & 5.90 & 10 & 11.80 & 70 & 82.4 & 85 & 100 & & \\
\hline
\end{tabular}

Sumber : Data Primer 2016

Hubungan Jumlah Tanggungan terhadap Tingkat kunjungan Ibu dalam Penimbangan Balita ke Posyandu di Wilayah Kerja Puskesmas Suradita Kecamatan Cisauk Kabupaten Tangerang Propinsi Banten Tahun 2016 dapat dianalisa dari tabel 8 berikut ini.

Tanggungan ibu kurang dari 4 orang jika dibandingkan dengan ibu dengan jumlah tanggungan lebih dari 4 orang menunjukan bahwa $60 \%$ melakukan kunjungan lebih dari 8 kali setahun dan ibu dengan tanggungan lebih dari 4 orang 87.1 $\%$ setahun.

Hasil uji statistik dengan Chi-Square menunjukkan bahwa nilai Probabilitas $(\mathrm{p})=$
0,016 yang berarti $p<0,05$ artinya $\mathrm{H} 0$ ditolak dan $\mathrm{H} 1$ diterima, hal ini berarti ada terjadi hubungan yang signifikan antara jumlah tanggungan ibu terhadap tingkat kunjungan penimbangan balita ke posyandu,nilai korellasi didapat sebesar 0,309 menunjukan hubungan yang terjadi cukup kuat.

Ini berarti bahwa jumlah tanggungan memiliki hubungan yang signifikan terhadap Tingkat kunjungan Ibu dalam Penimbangan Balita ke Posyandu di Wilayah Kerja Puskesmas Suradita Kecamatan Cisauk Kabupaten Tangerang Propinsi Banten Tahun 2016.

Tabel 9. Hubungan Suku Bangsa terhadap Tingkat kunjungan Ibu dalam Penimbangan Balita ke Posyandu di Wilayah Kerja Puskesmas Suradita Kecamatan Cisauk Kabupaten Tangerang Propinsi Banten Tahun 2016.

\begin{tabular}{|c|c|c|c|c|c|c|c|c|c|c|}
\hline \multirow{3}{*}{$\begin{array}{c}\text { Suku } \\
\text { Bangsa } \\
\text { Ibu Balita }\end{array}$} & \multicolumn{6}{|c|}{$\begin{array}{c}\text { Tingkat Kunjungan Ibu Balita ke } \\
\text { Posyandu }\end{array}$} & & & \multirow{3}{*}{$\begin{array}{c}\text { Koefisien } \\
\text { Korellasi } \\
\quad(\mathbf{r})\end{array}$} & \multirow{3}{*}{$\begin{array}{c}\text { Nilai } \\
\rho\end{array}$} \\
\hline & \multicolumn{2}{|c|}{$\begin{array}{c}\text { Tidak } \\
\text { Pernah }\end{array}$} & \multicolumn{2}{|c|}{$\begin{array}{l}\leq \mathbf{8 X} \text { dalam } \\
\text { Setahun }\end{array}$} & \multicolumn{2}{|c|}{$\begin{array}{c}\geq 8 \mathrm{X} \\
\text { dalam } \\
\text { Setahun }\end{array}$} & \multicolumn{2}{|c|}{ Jumlah } & & \\
\hline & $\mathbf{n}$ & $\%$ & $\mathbf{N}$ & $\%$ & $\mathbf{N}$ & $\%$ & $\mathbf{n}$ & $\%$ & & \\
\hline Batak & 1 & 20.0 & 1 & 10.0 & 7 & 10.0 & 9 & 10.6 & & \\
\hline Jawa & 4 & 80.0 & 3 & 30.0 & 34 & 48.6 & 41 & 48.2 & 0051 & 0307 \\
\hline Sunda & 0 & 0.00 & 4 & 40.0 & 26 & 37.1 & 30 & 35.3 & & \\
\hline Banjar & 0 & 0.00 & 1 & 10.0 & 1 & 1.40 & 2 & 240 & & \\
\hline
\end{tabular}




\begin{tabular}{|l|c|c|c|c|c|c|c|c|c|c|}
\hline Lainnya & $\mathbf{0}$ & $\mathbf{0 . 0 0}$ & $\mathbf{1}$ & $\mathbf{1 0 . 0}$ & $\mathbf{2}$ & $\mathbf{2 . 9 0}$ & $\mathbf{3}$ & $\mathbf{3 . 5 0}$ & & \\
\cline { 1 - 8 } Total & $\mathbf{5}$ & $\mathbf{5 . 9 0}$ & $\mathbf{1 0}$ & $\mathbf{1 1 . 8 0}$ & $\mathbf{7 0}$ & $\mathbf{8 2 . 4}$ & $\mathbf{8 5}$ & $\mathbf{1 0 0}$ & & \\
\hline
\end{tabular}

Sumber : Data Primer 2016

Hubungan Suku Bangsa terhadap Tingkat kunjungan Ibu dalam Penimbangan Balita ke Posyandu di Wilayah Kerja Puskesmas Suradita Kecamatan Cisauk Kabupaten Tangerang Propinsi Banten Tahun 2016 menunjukan dominasi suku Jawa dan Sunda.

Hasil uji statistic dengan Chi-Square menunjukkan bahwa nilai probabilitas dihasilkan $(p)=0,397$ yang berarti $p>0,05$ artinya Ho diterima dan $\mathrm{H} 1$ ditolak.

Kesimpulannya adalah tidak ada hubungan yang signifikan antara suku bangsa responden dengan tingkat kunjungan ibu dalam penimbangan balita ke posyandu di Wilayah Kerja Puskesmas Suradita Kecamatan Cisauk Kabupaten Tangerang Propinsi Banten Tahun 2016

Tabel 10. Hubungan Agama Yang dianut Ibu Balita terhadap Tingkat kunjungan Ibu dalam Penimbangan Balita ke Posyandu di Wilayah Kerja Puskesmas Suradita

Kecamatan Cisauk Kabupaten Tangerang Propinsi Banten Tahun 2016.

\begin{tabular}{|c|c|c|c|c|c|c|c|c|c|c|}
\hline \multirow{3}{*}{$\begin{array}{c}\text { Agama } \\
\text { Yang dianut } \\
\text { Ibu Balita }\end{array}$} & \multicolumn{6}{|c|}{$\begin{array}{c}\text { Tingkat Kunjungan Ibu Balita ke } \\
\text { Posyandu }\end{array}$} & & & \multirow{3}{*}{$\begin{array}{l}\text { Koefisien } \\
\text { Korellasi } \\
\quad(\mathbf{r})\end{array}$} & \multirow{3}{*}{$\begin{array}{c}\text { Nilai } \\
\rho\end{array}$} \\
\hline & \multicolumn{2}{|c|}{ Tidak Pernah } & \multicolumn{2}{|c|}{$\begin{array}{c}\leq 8 X \\
\text { dalam } \\
\text { Setahun }\end{array}$} & \multicolumn{2}{|c|}{$\begin{array}{c}\geq 8 \mathrm{X} \\
\text { dalam } \\
\text { Setahun }\end{array}$} & \multicolumn{2}{|c|}{ Jumlah } & & \\
\hline & $\mathbf{n}$ & $\%$ & $\mathbf{N}$ & $\%$ & $\mathbf{N}$ & $\%$ & $\mathbf{n}$ & $\%$ & & \\
\hline Islam & 5 & 100.0 & 7 & 70.0 & 48 & 68.6 & 60 & 70.6 & & \\
\hline Kristen & $\mathbf{0}$ & 0.00 & 2 & 20.0 & 8 & 11.4 & 10 & 11.8 & & \\
\hline Hindu & $\mathbf{0}$ & 0.00 & $\mathbf{0}$ & 0.00 & 3 & 4.30 & 3 & 3.50 & & \\
\hline Budha & $\mathbf{0}$ & 0.00 & 1 & 10.0 & 4 & 5.70 & 5 & 5.90 & 0.150 & 0.804 \\
\hline Lainnya & $\mathbf{0}$ & 0.00 & $\mathbf{0}$ & 0.00 & 7 & 10.0 & 7 & 8.20 & & \\
\hline Total & 5 & 5.90 & 10 & 11.8 & 70 & 82.4 & 85 & 100 & & \\
\hline
\end{tabular}

Sumber : Data Primer 2016

Hubungan Agama Yang dianut Ibu Balita terhadap Tingkat kunjungan Ibu dalam Penimbangan Balita ke Posyandu di Wilayah Kerja Puskesmas Suradita Kecamatan Cisauk Kabupaten Tangerang Propinsi Banten Tahun 2016 menunjukan $68.6 \%$ ibu beragama islam melakukan kunjungan ke posyandu lebih dari 8 kali dalam setahun.

Dan secara keseluruhan $82.4 \%$ ibu beragama melakukan kunjungan ke posyandu lebih dari 8 kali dalam setahun.
Hasil uji perhitungan statistik dengan menggunakan uji Chi-Square menunjukkan bahwa nilai probabilitas $(p)=0,804$ yang berarti $p>0,05$ artinya Ho diterima dan H1 ditolak dan $r$ sebesar 0,150.

Kesimpulannya adalah tidak ada hubungan yang signifikan antara agama yang dianut dengan tingkat kunjungan ibu dalam penimbangan balita ke posyandu di Wilayah Kerja Puskesmas Suradita Kecamatan Cisauk Kabupaten Tangerang Propinsi Banten Tahun 2016. 
Tabel 11. Hubungan Tingkat Pendidikan Ibu dengan Tingkat kunjungan Ibu dalam Penimbangan Balita ke Posyandu di Wilayah Kerja Puskesmas Suradita Kecamatan Cisauk Kabupaten Tangerang Propinsi Banten Tahun 2016.

\begin{tabular}{|c|c|c|c|c|c|c|c|c|}
\hline \multirow{3}{*}{$\begin{array}{c}\text { Tingkat } \\
\text { Pendidikan } \\
\text { Ibu }\end{array}$} & \multicolumn{6}{|c|}{$\begin{array}{c}\text { Tingkat } \\
\text { Kunjungan Ibu Balita ke Posyandu }\end{array}$} & \multirow{2}{*}{\multicolumn{2}{|c|}{ Jumlah }} \\
\hline & \multicolumn{2}{|c|}{$\begin{array}{l}\text { Tidak } \\
\text { Pernah }\end{array}$} & \multicolumn{2}{|c|}{$\begin{array}{l}\leq 8 \times \text { dalam } \\
\text { Setahun }\end{array}$} & \multicolumn{2}{|c|}{$\begin{array}{l}\geq 8 \times \text { dalam } \\
\text { Setahun }\end{array}$} & & \\
\hline & $\mathbf{n}$ & $\%$ & $\mathbf{N}$ & $\%$ & $\mathbf{N}$ & $\%$ & $\mathbf{n}$ & $\%$ \\
\hline Dasar & 0 & 0 & 3 & 6.8 & 41 & 93.2 & 44 & 100 \\
\hline Menengah & $\mathbf{0}$ & $\mathbf{0}$ & 4 & 16.0 & 21 & 84.0 & 25 & 100 \\
\hline Tinggi & 5 & 31.3 & 3 & 18.8 & 8 & 50.0 & 16 & 100 \\
\hline Total & 5 & 5.9 & 10 & 11.8 & 70 & 82.4 & 85 & 100 \\
\hline
\end{tabular}

Sumber : Data Primer 2016

Hubungan Tingkat Pendidikan Ibu dengan Tingkat kunjungan Ibu dalam Penimbangan Balita ke Posyandu di Wilayah Kerja Puskesmas Suradita Kecamatan Cisauk Kabupaten Tangerang Propinsi Banten Tahun 2016 ibu dengan
Pendidikan dasar $93.2 \%$ lebih dari 8 kali dalam setahun, $84 \%$ berpendidikan menengah dan $50 \%$ berpendidikan tinggi. Yang berkunjung ke posyandu didominasi ibu dengan tingkat Pendidikan dasar dan menengah.

Tabel 12. Hasil Perhitungan nilai koefisien Korellasi dan Nilai Chi square Test Tingkat Pendidikan Ibu dengan Tingkat kunjungan Ibu dalam Penimbangan Balita ke Posyandu di Wilayah Kerja Puskesmas Suradita Kecamatan Cisauk Kabupaten Tangerang Propinsi Banten Tahun 2016.

\begin{tabular}{|l|c|c|}
\hline \multirow{2}{*}{$\begin{array}{c}\text { Tingkat Pendidikan } \\
\text { Ibu }\end{array}$} & \multicolumn{2}{|c|}{ Tingkat } \\
\cline { 2 - 3 } & $\begin{array}{c}\text { Kunjungan Ibu Balita ke Posyandu } \\
\text { Nilai Koefisien Korelasi } \\
(\mathbf{r})\end{array}$ & $\begin{array}{c}\text { Nilai } \\
\boldsymbol{\rho}\end{array}$ \\
\hline Dasar & \multirow{2}{*}{$\mathbf{0 . 4 6 3}$} & $\mathbf{0 . 0 0 0}$ \\
\hline Menengah & & \\
\hline Tinggi & & \\
\hline
\end{tabular}

\section{Sumber : Data Primer 2016}

Berdasarkan hasil uji statistik dengan menggunakan uji Chi-Square menunjukkan bahwa probabilitas $(\mathrm{p})=0,000$ yang berarti $\mathrm{p}<0,05$ artinya $\mathrm{H} 1$ diterima dan Ho ditolak Nilai korelasi didapat sebesar 0.463

Kesimpulannya adalah tingkat Pendidikan ibu ada hubungan yang siginifikan dengan tingkat kunjungan ibu dalam penimbangan balita ke posyandu di menandakan terjadinya korelasi atau hubungan yang cukup kuat antara tinggkat pedidikan ibu dengan tingkat kunjungan ibu balita ke posyandu.

Wilayah Kerja Puskesmas Suradita Kecamatan Cisauk Kabupaten Tangerang Propinsi Banten Tahun 2016. 
Tabel 13. Hubungan Pekerjaan Ibu dengan Tingkat Kunjungan Ibu dalam Penimbangan Balita ke Posyandu di Wilayah Kerja Puskesmas Suradita Kecamatan Cisauk Kabupaten Tangerang Propinsi Banten Tahun 2016.

\begin{tabular}{|c|c|c|c|c|c|c|c|c|}
\hline \multirow{3}{*}{ Pekerjaan Ibu } & \multicolumn{6}{|c|}{ Tingkat Kunjungan Ibu Balita ke Posyandu } & \multirow{2}{*}{\multicolumn{2}{|c|}{ Jumlah }} \\
\hline & \multicolumn{2}{|c|}{ Tidak Pernah } & \multicolumn{2}{|c|}{$\underset{\text { Setahun }}{\leq 8 X \text { dalam }}$} & \multicolumn{2}{|c|}{$\begin{array}{c}\geq 8 \mathrm{X} \\
\text { dalam } \\
\text { Setahun }\end{array}$} & & \\
\hline & $\mathbf{n}$ & $\%$ & $\mathbf{N}$ & $\%$ & $\mathbf{N}$ & $\%$ & $\mathbf{n}$ & $\%$ \\
\hline $\begin{array}{l}\text { Ibu Rumah } \\
\text { Tangga }\end{array}$ & 1 & 20.0 & $\mathbf{1 0}$ & 100 & 41 & 58.6 & 52 & 61.2 \\
\hline $\begin{array}{l}\text { Pegawai Negeri } \\
\text { Sipil }\end{array}$ & 4 & 80.0 & $\mathbf{0}$ & 0.00 & $\mathbf{1 0}$ & 14.3 & 14 & 16.5 \\
\hline $\begin{array}{l}\text { Pegawai } \\
\text { Swasta }\end{array}$ & $\mathbf{0}$ & 0.00 & $\mathbf{0}$ & 0.00 & 19 & 27.1 & 19 & 22.4 \\
\hline Total & 5 & 100 & $\mathbf{1 0}$ & 100 & 70 & 100 & 85 & 100 \\
\hline
\end{tabular}

Sumber : Hasil olah data 2016

Hubungan Pekerjaan Ibu dengan Tingkat Kunjungan Ibu dalam Penimbangan Balita ke Posyandu di Wilayah Kerja Puskesmas Suradita
Kecamatan Cisauk Kabupaten Tangerang Propinsi Banten Tahun 2016 sebanyak $58.6 \%$ yang berkunjung didominasi ibu yang bekerja sebagai ibu rumah tangga.

Tabel 14. Hasil Perhitungan nilai koefisien Korellasi dan Nilai Chi square Test Jenis Pekerjaan Ibu dengan Tingkat Kunjungan Ibu dalam Penimbangan Balita ke Posyandu di Wilayah Kerja Puskesmas Suradita Kecamatan Cisauk Kabupaten Tangerang Propinsi Banten Tahun 2016

\begin{tabular}{|l|c|c|}
\hline \multirow{2}{*}{ Jenis Pekerjaan Ibu } & \multicolumn{2}{|c|}{ Tingkat Kunjungan Ibu Balita ke Posyandu } \\
\cline { 2 - 2 } & $\begin{array}{c}\text { Nilai Koefisien } \\
\text { Korelasi } \\
(\mathbf{r})\end{array}$ & $\begin{array}{c}\text { Nilai } \\
\rho\end{array}$ \\
\cline { 1 - 1 } Ibu Rumah Tangga & $\mathbf{0 . 1 1 0}$ & $\mathbf{0 . 0 0 0}$ \\
\cline { 1 - 1 } Pegawai Negeri Sipil & & \\
\hline Pegawai Swasta & &
\end{tabular}

Sumber : Data Primer 2016

Hasil penghitungan uji statistik dengan menggunakan uji Chi-Square antara jenis pekerjaan ibu dengan tinggkat kunjungan ibu balita ke posyandu menunjukkan bahwa probabilitas $(\mathrm{p})=$ 0,000 yang berarti $\mathrm{p}<0,05$ artinya Ho ditolak dan $\mathrm{H} 1$ diterima.

Ibu yang bekerja baik itu sebagai ibu rumah tangga,pegawai negeri sipil dan pegawai swasta sebenarnya sama-sama memiliki kesempatan dalam membawa anak balitanya ke posyandu karena untuk membawa anak ke posyandu sebenarnya tidak memerlukan waktu yang lama.
Kesimpulannya adalah bahwa ada hubungan yang signifikan antara jenis pekerjaan ibu sebagai responden dengan tingkat Kunjungan ibu dalam penimbangan balita ke posyandu. Nilai koefisien korellasi yang dihasilkan adalah sebesar 0.110 ini menunjukan hubungan yang terjadi lemah.

Dalam penelitian ini tingkat Kunjungan ibu yang bekerja sebagai ibu rumah tangga melakukan kunjungan lebih dari 8 kali dalam setahun untuk membawakan anak balitanya ke posyandu.

Inilah yang mejadi perbedaan mendasar bahwa ibu yang bekerja sebagai ibu rumah tangga terlihat lebih rajin 
mengunjungi posyandu untuk melakukan penimbangan balitanya jika kita bandingkan dengan ibu yang bekerja sebagai PNS ataupun pegawai swasta, kondisi ini menandakan bahwa tingkat kunjungan ibu yang bekerja sebagai ibu rumah tangga lebih rajin melakukan kunjungan ke posyandu..

Tabel 15. Hubungan Pengetahuan Ibu dengan Tingkat Kunjungan Ibu dalam Penimbangan Balita ke Posyandu di Wilayah Kerja Puskesmas Suradita Kecamatan Cisauk Kabupaten Tangerang Propinsi Banten Tahun 2016.

\begin{tabular}{|c|c|c|c|c|c|c|c|c|}
\hline \multirow{3}{*}{$\begin{array}{l}\text { Pengetahuan } \\
\text { Ibu }\end{array}$} & \multicolumn{6}{|c|}{$\begin{array}{c}\text { Tingkat } \\
\text { Kunjungan Ibu Balita ke Posyandu }\end{array}$} & \multirow{2}{*}{\multicolumn{2}{|c|}{ Jumlah }} \\
\hline & \multicolumn{2}{|c|}{ Tidak Pernah } & \multicolumn{2}{|c|}{$\begin{array}{l}\leq 8 \times \text { dalam } \\
\text { Setahun }\end{array}$} & \multicolumn{2}{|c|}{$\begin{array}{l}\geq 8 \times \text { dalam } \\
\text { Setahun }\end{array}$} & & \\
\hline & $\mathbf{n}$ & $\%$ & $\mathbf{N}$ & $\%$ & $\mathbf{N}$ & $\%$ & $\mathbf{n}$ & $\%$ \\
\hline Baik & 5 & 10.9 & 10 & 21.7 & 31 & 67.4 & 46 & 54.1 \\
\hline Cukup & 0 & $\begin{array}{l}0.00 \\
\end{array}$ & $\mathbf{0}$ & 0.00 & 23 & 32.9 & 23 & 27.1 \\
\hline Kurang & $\mathbf{0}$ & 0.00 & $\mathbf{0}$ & 0.00 & 16 & 22.9 & 16 & 18.8 \\
\hline Total & 5 & 5.90 & 10 & 11.80 & 70 & 82.4 & 85 & 100 \\
\hline
\end{tabular}

Sumber : Hasil olah data 2016

Gambaran hubungan Pengetahuan Ibu dengan Tingkat Kunjungan Ibu dalam Penimbangan Balita ke Posyandu di Wilayah Kerja Puskesmas Suradita Kecamatan Cisauk Kabupaten Tangerang Propinsi Banten Tahun 2016 menunjukan ibu dengan pengetahuan yang baik $67.4 \%$ melakukan kunjungan ke posyandu lebih dari 8 kali dalam setahun.
Kondisi ini mengindikasikan bahwa pengetahuan ibu yang semakin baik akan melakukan kunjungan ke posyandu lebih baik,namun demikian secara keseluruhan pengetahun ibu baik dengan pengetahuannya yang sudah baik, cukup maupun kurang total $82.4 \%$ mereka telah melakukan kunjungan posyandu lebih dari 8 kali dalam satu tahun.

Tabel 16. Hasil Perhitungan nilai koefisien Korellasi dan Nilai Chi square Test Pengetahuan Ibu dengan Tingkat Kunjungan Ibu dalam Penimbangan Balita ke Posyandu di Wilayah Kerja Puskesmas Suradita Kecamatan Cisauk Kabupaten Tangerang Propinsi Banten Tahun 2016

\begin{tabular}{|c|c|c|}
\hline \multirow[t]{2}{*}{ Pengetahuan Ibu } & \multicolumn{2}{|c|}{$\begin{array}{c}\text { Tingkat } \\
\text { Kunjungan Ibu Balita ke Posyandu }\end{array}$} \\
\hline & Nilai Koefisien Korelasi ( $\mathbf{r}$ ) & Nilai $\rho$ \\
\hline Baik & \multirow{3}{*}{0.359} & \multirow{3}{*}{0.004} \\
\hline Cukup & & \\
\hline Kurang & & \\
\hline
\end{tabular}

\section{Sumber : Data Primer 2016}

Berdasarkan hasil perhitungan melalui uji statistik dengan menggunakan uji ChiSquare seperti pada Tabel 16 Hasil Perhitungan nilai koefisien Korellasi dan Nilai Chi square Test Pengetahuan Ibu dengan Tingkat Kunjungan Ibu dalam Penimbangan Balita ke Posyandu di Wilayah Kerja Puskesmas Suradita Kecamatan Cisauk Kabupaten Tangerang Propinsi Banten Tahun 2016 menunjukkan bahwa probabilitas $(p)=0,004$ yang berarti $\mathrm{p}<0,05$ artinya Ho ditolak dan $\mathrm{H} 1$ diterima.

Hasil perhitungan koefisien korellasi didapat sebesar 0.359 menunjukan hubungan yang terjadi positip dan cukup kuat, Kesimpulannya adalah ada hubungan yang siginifikan antara pengetahuan responden dengan tingkat Kunjungan ibu dalam penimbangan balita ke posyandu. 
Di posyandu wilayah kerja puskesmas Suradita Kecamatan Cisauk Kabupaten Tangerang Propinsi Banten Tahun 2016 menunjukkan bahwa tingkat pengetahuan ibu mengenai posyandu berdasarkan penilaian yang dilakukan dengan menggunakan kuesioner secara relative pengetahuan ibu sudah baik, hal ini dapat dilihat dari ibu yang pengetahuannya baik, tingkat Kunjungannya ke posyandu juga sudah baik.

Maka dapat disimpulkan bahwa pengetahuan ibu tentang posyandu sangat berpengaruh terhadap tingkat Kunjungan ibu untuk menimbangkan anak balitanya ke posyandu, karena semakin baik pengetahuan ibu tentang pentingnya posyandu maka akan semakin baik kemauan ibu untuk membawakan anaknya ke posyandu dan ibu juga akan mendapatkan manfaat yang dari membawa anaknya ke posyandu,

Karena di posyandu selain melakukan kegiatan penimbangan dan imunisasi pada bayi dilakukan juga penyuluhan kesehatan kepada ibu balita yang dilakukan oleh petugas kesehatan yang hadir pada pelaksanaan posyandu.

Penyuluhan kesehatan dilakukan dengan memberikan materi kesehatan yang berganti setiap bulannya sehingga dapat meningkatkan pengetahuan ibu -ibu yang datang ke posyandu khususnya pengetahuan kesehatan.
Dari hasil analisis bivariat masih ditemukan sebanyak 5 responden $(10.9 \%)$ ibu yang pengetahuannya mengenai manfaat, kegiatan posyandu sudah baik namun tidak pernah ikut posyandu dari hasil wawancara langsung ibu tersebut menyatakan malas membawa balitanya untuk ditimbang karena ibu merasa kurang mendapatkan manfaat dari penimbangan balita dengan alasan cuman ditimbang saja tidak pernah diukur tinggi badan anak,

Selain alasan tersebut ada juga ibu menyatakan jarang membawa balita ke posyandu dikarenakan tidak ada timbangan dewasa karena anak balita usia 4 tahun lebih tidak mau ditimbang dengan timbangan sarung/dacin terbukti anak menangis saat ditimbang,

Selain itu anak lagi tidur pada saat posyandu dilaksanakan dan ibu enggan untuk membangunkan anak, alasan lainnya dikarenakan ibu merasa bahwa anak mereka dalam kondisi sehat, bobot badan anak normal dan anak aktif maka ibu jarang membawa balita ke posyandu

Akan tetapi jikalau di Posyandu ada diumumkan akan diberikan hadiah atau bubur atau makanan tambahan para ibu dipastikan hadir di hari buka posyandu tersebut dan masih banyak yang ibu yang berpendapat bahwa di posyandu hanya melaksanakan imunisasi dan penimbangan saja tanpa ada kegiatan lainnya.

Tabel 17. Hubungan Sikap Ibu dengan Tingkat Kunjungan Ibu dalam Penimbangan Balita ke Posyandu di Wilayah Kerja Puskesmas Suradita Kecamatan Cisauk Kabupaten Tangerang Propinsi Banten Tahun 2016.

\begin{tabular}{|c|c|c|c|c|c|c|c|c|}
\hline \multirow{3}{*}{ Sikap Ibu } & \multicolumn{6}{|c|}{ Tingkat Kunjungan Ibu Balita ke Posyandu } & \multirow{2}{*}{\multicolumn{2}{|c|}{ Jumlah }} \\
\hline & \multicolumn{2}{|c|}{ Tidak Pernah } & \multicolumn{2}{|c|}{$\begin{array}{l}\leq 8 X \text { dalam } \\
\text { Setahun }\end{array}$} & \multicolumn{2}{|c|}{$\begin{array}{l}\geq 8 \times \text { dalam } \\
\text { Setahun }\end{array}$} & & \\
\hline & $\mathbf{n}$ & $\%$ & $\mathbf{N}$ & $\%$ & $\mathbf{N}$ & $\%$ & $\mathbf{n}$ & $\%$ \\
\hline Baik & $\mathbf{0}$ & 0.00 & 0 & $\mathbf{0 . 0 0}$ & 27 & 100 & 27 & 100 \\
\hline Cukup & 1 & 2.10 & 6 & 12.50 & 41 & 85.40 & 48 & 100 \\
\hline Kurang & 4 & 40.0 & 4 & 40.0 & 2 & 20.0 & 10 & 100 \\
\hline Total & 5 & 5.90 & 10 & 11.80 & 70 & 82.4 & 85 & 100 \\
\hline
\end{tabular}

Sumber : Hasil olah data 2016 
Hubungan Sikap Ibu dengan Tingkat Kunjungan Ibu dalam Penimbangan Balita ke Posyandu di Wilayah Kerja Puskesmas Suradita Kecamatan Cisauk Kabupaten Tangerang Propinsi Banten Tahun 2016.

Hasil analisis Bivariat menunjukan $100 \%$ ibu yang bersikap baik tingkat partisipasinya sudah baik, sedangkan diantara ibu yang bersikap kurang hanya $20.0 \%$.

Sikap ibu terhadap posyandu yang baik mempunyai peranan penting dalam peningkatan partisipasi atau tingkakt kunjungan ibu untuk menimbangkan anaknya ke posyandu.

Tabel 18. Hasil Perhitungan nilai koefisien Korellasi dan Nilai Chi square Test Sikap Ibu dengan Tingkat Kunjungan Ibu dalam Penimbangan Balita ke Posyandu di Wilayah Kerja Puskesmas Suradita Kecamatan Cisauk Kabupaten Tangerang Propinsi Banten Tahun 2016.

\begin{tabular}{|l|c|c|}
\hline \multirow{2}{*}{ Sikap Ibu } & \multicolumn{2}{|c|}{$\begin{array}{c}\text { Tingkat Kunjungan Ibu Balita ke } \\
\text { Posyandu }\end{array}$} \\
\cline { 2 - 3 } & $\begin{array}{c}\text { Nilai Koefisien } \\
\text { Korelasi } \\
(\mathbf{r})\end{array}$ & $\begin{array}{c}\text { Nilai } \\
\rho\end{array}$ \\
\hline Baik & \multirow{2}{*}{0.549} & 0.000 \\
\hline Cukup & \multicolumn{2}{|c|}{} \\
\hline Kurang & & \\
\hline
\end{tabular}

Sumber : Data Primer 2016

Hasil uji statistic sikap ibu balita dengan tingkat kunjungan ke posyandu menggunakan uji Chi-Square menunjukkan bahwa probabilitas $(\mathrm{p})=0,000$ yang berarti $\mathrm{p}<0,05$ artinya Ho ditolak dan $\mathrm{H} 1$ diterima dan nilai koefisien korellasi didapat sebesar 0.549 menunjukan tingkat hubungan cukup kuat,

Dari hasil pengujian tersebut kesimpulannya adalah ada hubungan yang signifikan antara sikap responden dengan tingkat Kunjungan ibu dalam penimbangan balita ke posyandu.

Sejalan dengan Azwar (2007) yang menyatakan bahwa pembentukan sikap seseorang banyak dipengaruhi oleh banyak faktor baik yang bersifat intrinsik maupun ekstrinsik orang tersebut. Faktor tersebut biasa berupa pengalaman pribadi, pengaruh orang lain, kebudayaan, media informasi dan faktor emosional orang itu sendiri.
Kelompok ibu yang sikapnya terhadap pelaksanaan posyandu baik maka tingkat partisipasinya atau tingkat kunjungan ke posyandu akan jauh lebih baik dibanding ibu yang sikapnya terhadap pelaksanaan posyandu masih rendah.

Sikap ibu terhadap pelaksanaan posyandu akan lebih baik apabila ibu sering mengikuti penyuluhan pada saat pelaksanaan posyandu yang disampaikan oleh kader posyandu maupun petugas kesehatan.

Kehadiran kader posyandu, jarak posyandu, dan kemudian kelengkapan peralatan posyandu dengan tingkat Kunjungan ibu dalam penimbangan balita ke posyandu di Wilayah Kerja Puskesmas Puskesmas Suradita Kecamatan Cisauk Kabupaten Tangerang Propinsi Banten Tahun 2016 dapat dianalisa dari pemaparan pada tabel berikut ini: 
Tabel 19. Hubungan Kehadiran Kader Posyandu dengan Tingkat Kunjungan Ibu dalam Penimbangan Balita ke Posyandu di Wilayah Kerja Puskesmas Suradita Kecamatan Cisauk Kabupaten Tangerang Propinsi Banten Tahun 2016.

\begin{tabular}{|c|c|c|c|c|c|c|c|c|c|c|}
\hline \multirow{3}{*}{$\begin{array}{c}\text { Kehadiran } \\
\text { Kader } \\
\text { Posyandu }\end{array}$} & \multicolumn{6}{|c|}{$\begin{array}{c}\text { Tingkat Kunjungan Ibu Balita ke } \\
\text { Posyandu }\end{array}$} & & & \multirow{3}{*}{$\begin{array}{c}\text { Koefisie } \\
\text { n } \\
\text { Korella } \\
\text { si } \\
(\mathbf{r})\end{array}$} & \multirow{3}{*}{$\begin{array}{c}\text { Nilai } \\
\rho\end{array}$} \\
\hline & \multicolumn{2}{|c|}{$\begin{array}{c}\text { Tidak } \\
\text { Pernah }\end{array}$} & \multicolumn{2}{|c|}{$\begin{array}{c}\leq \mathbf{8 X} \text { dalam } \\
\text { Setahun }\end{array}$} & \multicolumn{2}{|c|}{$\begin{array}{c}\geq 8 \mathrm{X} \\
\text { dalam } \\
\text { Setahun }\end{array}$} & \multicolumn{2}{|c|}{ Jumlah } & & \\
\hline & $\mathbf{n}$ & $\%$ & $\mathbf{n}$ & $\%$ & $\mathbf{n}$ & $\%$ & $\mathbf{n}$ & $\%$ & & \\
\hline $\begin{array}{l}\text { Tidak Pernah } \\
\text { Hadir }\end{array}$ & $\mathbf{0}$ & 0.00 & 2 & 13.30 & $\begin{array}{l}\mathbf{1} \\
\mathbf{3}\end{array}$ & 86.70 & 15 & 100.0 & & \\
\hline Jarang Hadir & 5 & 25.0 & $\mathbf{0}$ & 0.00 & $\begin{array}{l}1 \\
5\end{array}$ & 75.00 & 20 & 100.0 & 006 & 0001 \\
\hline Selalu Hadir & $\mathbf{0}$ & 0.00 & 8 & 16.0 & $\begin{array}{l}4 \\
2\end{array}$ & 84.00 & 50 & 100.0 & 0.002 & 0.001 \\
\hline Total & 5 & 5.90 & $\mathbf{1 0}$ & 11.80 & $\begin{array}{l}7 \\
\mathbf{0}\end{array}$ & 84.20 & 85 & 100.0 & & \\
\hline
\end{tabular}

\section{Sumber : Hasil olah data 2016}

Hubungan Kehadiran Kader Posyandu dengan Tingkat Kunjungan Ibu dalam Penimbangan Balita ke Posyandu di Wilayah Kerja Puskesmas Suradita Kecamatan Cisauk Kabupaten Tangerang Propinsi Banten Tahun 2016 menunjukan $86.7 \%$ kader tidak pernah hadir lebih dari 8 kali dalam setahun dan $84 \%$ kader selalu hadir lebih dari 8 kali dalam setahun. Secara keseluruhan kehadiran kader posyandu $84.20 \%$ kehadirannya di posyandu lebih dari 8 kali dalam setahun.

Kondisi ini menggambarkan tingkat kehadiran kader posyandu di Wilayah Kerja Puskesmas Suradita Kecamatan Cisauk Kabupaten Tangerang Propinsi Banten Tahun 2016 sudah berjalan sangat tinggi, hal ini menandakan kegiatan posyandu sudah berjalan dengan kontinuitas yang baik sebenarnya.

Hasil perhitungan denga uji statistik menggunakan uji Chi-Square menunjukkan bahwa probabilitas $(\mathrm{p})=0,001$ yang berarti $\mathrm{p}<0,05$ artinya Ho ditolak dan H1 diterima. Kemudian besaran koefisien korelasi diperoleh sebesar 0.062 ini menggambarkan bahwa hubungan yang terjadi sangatlah lemah.

Kesimpulan yang didapat dari hasil perhitungan tersebut adalah bahwa ada hubungan yang signifikan antara kehadiran kader-kader posyandu dengan tingkat kunjungan ibu menimbangkan anaknya ke posyandu.

Tabel 20. Hubungan Kelengkapan Peralatan dan Sarana Posyandu dengan Tingkat Kunjungan Ibu dalam Penimbangan Balita ke Posyandu di Wilayah Kerja Puskesmas Suradita Kecamatan Cisauk Kabupaten Tangerang Propinsi Banten Tahun 2016.

\begin{tabular}{|c|c|c|c|c|c|c|c|c|c|c|}
\hline \multirow{3}{*}{$\begin{array}{c}\text { Kelengkapan } \\
\text { Peralatan dan } \\
\text { Sarana Posyandu }\end{array}$} & \multicolumn{6}{|c|}{$\begin{array}{c}\text { Tingkat Kunjungan Ibu Balita ke } \\
\text { Posyandu }\end{array}$} & \multirow{2}{*}{\multicolumn{2}{|c|}{ Jumlah }} & \multirow{3}{*}{$\begin{array}{c}\text { Koefis } \\
\text { ien } \\
\text { Korell } \\
\text { asi } \\
(\mathbf{r})\end{array}$} & \multirow{3}{*}{$\begin{array}{c}\text { Nilai } \\
\rho\end{array}$} \\
\hline & \multicolumn{2}{|c|}{$\begin{array}{c}\text { Tidak } \\
\text { Pernah }\end{array}$} & \multicolumn{2}{|c|}{$\begin{array}{c}\leq 8 X \\
\text { dalam } \\
\text { Setahun }\end{array}$} & \multicolumn{2}{|c|}{$\begin{array}{l}\geq 8 \times \text { dalam } \\
\text { Setahun }\end{array}$} & & & & \\
\hline & $\mathbf{n}$ & $\%$ & $\mathbf{N}$ & $\%$ & $\mathbf{N}$ & $\%$ & $\mathbf{n}$ & $\%$ & & \\
\hline Kurang Lengkap & 2 & 2.60 & 7 & 9.10 & 68 & 88.30 & 77 & 100 & \multirow{4}{*}{0.474} & \multirow{4}{*}{0.000} \\
\hline Cukup Lengkap & 3 & 60.0 & $\mathbf{0}$ & 0.00 & 2 & 40.0 & 5 & 100 & & \\
\hline Sangat Lengkap & $\mathbf{0}$ & 0.00 & 3 & $\begin{array}{c}100 . \\
0\end{array}$ & $\mathbf{0}$ & 0.00 & 3 & 100 & & \\
\hline Total & 5 & 5.90 & 10 & $\begin{array}{c}11.8 \\
0\end{array}$ & 70 & 82.40 & 85 & 100 & & \\
\hline
\end{tabular}

Sumber : Hasil olah data 2016 
Hubungan Kelengkapan Peralatan dan Sarana Posyandu dengan Tingkat Kunjungan Ibu dalam Penimbangan Balita ke Posyandu di Wilayah Kerja Puskesmas Suradita Kecamatan Cisauk Kabupaten Tangerang Propinsi Banten Tahun 2016 menunjukan kondisi yang serba terbatas dan kurang lengkap hal itu terlihat ada sekita $88.30 \%$ responden yang tingkat kehadirannya lebih dari 8 kali dalam setahun mengungkapkan bahwa kondisi peralatan dan sarana masihlah sangat kurang.

Hasil uji statistik dengan menggunakan uji Chi-Square menunjukkan bahwa probabilitas $(\mathrm{p})=0,000$ yang berarti $\mathrm{p}<$ 0,05 artinya Ho ditolak dan $\mathrm{H} 1$ diterima kemudian koefisien korellasi dtemukan sebesar 0.474. Kesimpulannya adalah ada hubungan yang signifikan antara kelengkapan peralatan dan sarana dengan tingkat partisipasi ibu dalam penimbangan balita ke posyandu.

Artinya apa jika tingkat peralatan sarana prasarana posyandu lengkap dan memadai maka tingkat kunjungan ibu ke posyandu juga akan meningkat.

Nilai koefisien korellasi yang ditemukan sebesar 0.474 menandakan bahwa keterkaitan atau hubungan antara peralatan sarana prasarana posyandu itu berkaitan cukup erat terahadap tingkat kunjungan ibu balita melakukan penimbangan.

Tabel 21. Hubungan Jarak Rumah Ke Posyandu dengan Tingkat Kunjungan Ibu dalam Penimbangan Balita ke Posyandu di Wilayah Kerja Puskesmas Suradita Kecamatan Cisauk Kabupaten Tangerang Propinsi Banten Tahun 2016.

\begin{tabular}{|c|c|c|c|c|c|c|c|c|c|c|}
\hline \multirow{3}{*}{$\begin{array}{c}\text { Jarak Rumah } \\
\text { Ke Posyandu }\end{array}$} & \multicolumn{6}{|c|}{$\begin{array}{c}\text { Tingkat Kunjungan Ibu Balita ke } \\
\text { Posyandu }\end{array}$} & & & \multirow{3}{*}{$\begin{array}{c}\text { Koefisien } \\
\text { Korellasi } \\
\quad(\mathbf{r})\end{array}$} & \multirow{3}{*}{$\begin{array}{c}\text { Nilai } \\
\rho\end{array}$} \\
\hline & \multicolumn{2}{|c|}{$\begin{array}{c}\text { Tidak } \\
\text { Pernah }\end{array}$} & \multicolumn{2}{|c|}{$\begin{array}{c}\leq 8 X \\
\text { dalam } \\
\text { Setahun }\end{array}$} & \multicolumn{2}{|c|}{$\begin{array}{l}\geq \text { X X dalam } \\
\text { Setahun }\end{array}$} & \multicolumn{2}{|c|}{ Jumlah } & & \\
\hline & $\mathbf{n}$ & $\%$ & $\mathbf{N}$ & $\%$ & $\mathbf{N}$ & $\%$ & $\mathbf{n}$ & $\%$ & & \\
\hline Jauh & 0 & 0.00 & $\mathbf{0}$ & 0.00 & 19 & 100.0 & 19 & 100 & & \\
\hline Cukup Jauh & 5 & 33.3 & $\mathbf{0}$ & 0.00 & 10 & 66.7 & 15 & 100 & & \\
\hline Sangat Dekat & $\mathbf{0}$ & 0.00 & 10 & 19.6 & 41 & 80.4 & 51 & 100 & 5 & 0.000 \\
\hline Total & 5 & 5.90 & 10 & 11.8 & 70 & 82.4 & 85 & 100 & & \\
\hline
\end{tabular}

Sumber : Hasil olah data 2016

Hubungan Jarak Rumah Ke Posyandu dengan Tingkat Kunjungan Ibu dalam Penimbangan Balita ke Posyandu di Wilayah Kerja Puskesmas Suradita Kecamatan Cisauk Kabupaten Tangerang Propinsi Banten Tahun 2016 menunjukkan bahwa $82.4 \%$ baik yang jaraknya jauh,cukup jauh an sangat dekat telah melakukan kunjungan ke posyandu lebih dari 8 kali dalam setahun.

Namun disini terlihat responden yang jarak dari rumah sangat dekat itu hanya $80.4 \%$ tingkat kehadirannya ke posyandu, temuan ini menggambarkan bahwa sepertinya jarak rumah ke posyandu bukan merupakan masalah yang sebenarnya merintangi ibu untuk menimbang anaknya di posyandu,jika kita analisis dari jarak responden yang jauh ternyata tingkat kunjungannya 100\% melakukan kunjungan lebih dari 8 kali.

Hasil uji statistik dengan menggunakan uji Chi-Square menunjukkan bahwa probabilitas $(\mathrm{p})=0,000$ yang berarti $\mathrm{p}<$ 0,05 artinya Ho ditolak dan H1 diterima.

Kesimpulannya adalah ada hubungan yang signifikan antara Jarak rumah ke posyandu dengan tingkat kunjungan ibu dalam penimbangan balita ke posyandu. Besaran nilai koefisien korellasi sebesar 0.065 menunjukan hubungan yang terjadi bersipat lemah.

Sikap kader dan sikap keluarga ibu dengan tingkat Kunjungan ibu dalam penimbangan balita ke posyandu di Wilayah Kerja Puskesmas Suradita Kecamatan Cisauk Kabupaten Tangerang 
Propinsi Banten Tahun 2016 adalah sebagai

berikut :

Tabel 22. Hubungan Sikap Dukungan Kader Posyandu dengan Tingkat Kunjungan Ibu dalam Penimbangan Balita ke Posyandu di Wilayah Kerja Puskesmas Suradita

Kecamatan Cisauk Kabupaten Tangerang Propinsi Banten Tahun 2016.

\begin{tabular}{|c|c|c|c|c|c|c|c|c|}
\hline \multirow{3}{*}{$\begin{array}{c}\text { Sikap } \\
\text { Dukungan } \\
\text { Kader Posyandu }\end{array}$} & \multicolumn{6}{|c|}{ Tingkat Kunjungan Ibu Balita ke Posyandu } & \multirow{2}{*}{\multicolumn{2}{|c|}{ Jumlah }} \\
\hline & \multicolumn{2}{|c|}{ Tidak Pernah } & \multicolumn{2}{|c|}{$\begin{array}{c}\leq 8 \times \text { dalam } \\
\text { Setahun }\end{array}$} & \multicolumn{2}{|c|}{$\begin{array}{l}\geq 8 \text { X dalam } \\
\text { Setahun }\end{array}$} & & \\
\hline & $\mathbf{n}$ & $\%$ & $\mathbf{N}$ & $\%$ & $\mathbf{N}$ & $\%$ & $\mathbf{n}$ & $\%$ \\
\hline Ada Dukungan & 2 & 40.0 & 1 & 20.0 & 2 & 40.0 & 5 & 100 \\
\hline Kurang Dukungan & $\mathbf{0}$ & $\mathbf{0 . 0 0}$ & 5 & 33.3 & 10 & 66.7 & 15 & 100 \\
\hline $\begin{array}{l}\text { Tidak Ada } \\
\text { Dukungan }\end{array}$ & 3 & 4.60 & 4 & 6.20 & 58 & 89.2 & 65 & 100 \\
\hline Total & 5 & 5.9 & 10 & 11.8 & 70 & 82.4 & 85 & 100 \\
\hline
\end{tabular}

Sumber : Hasil olah data 2016

Support atau dukungan positip sangatlah penting namun jika melihat hasil perhitungan uji bivariat terlihat bahwa jika kita bandingkan tingkat kunjungan ibu yang mendapat dukungan kader hanya $40 \%$ yang hadir ke posyandu lebih dari 8 kali dalam setahun, justeru ibu yang tidak mendapat dukungan kader $89.2 \%$ tingkat kunjungannya justeru lebih dari 8 kali dalam setahun kondisi ini sebenarnya dapat menggambarkan bahwa kesadaran ibu-ibu sebenarnya sudah cukup tinggi karena tanpa di dukung oleh kader mereka bisa hadir ke posyandu lebih dari 8 kali dalam setahun.

Tabel 23. Hasil Perhitungan nilai koefisien Korellasi dan Nilai Chi square Test Sikap dukungan kader dengan Tingkat Kunjungan Ibu dalam Penimbangan Balita ke Posyandu di Wilayah Kerja Puskesmas Suradita Kecamatan Cisauk Kabupaten Tangerang Propinsi

Banten Tahun 2016

\begin{tabular}{lcc}
\hline \multicolumn{1}{c}{$\begin{array}{c}\text { Sikap } \\
\text { Dukungan Kader } \\
\text { Posyandu }\end{array}$} & \multicolumn{2}{c}{ Tingkat Kunjungan Ibu Balita ke Posyandu } \\
\cline { 2 - 3 } & $\begin{array}{c}\text { Nilai Koefisien Korelasi } \\
(\mathbf{r})\end{array}$ & $\begin{array}{c}\text { Nilai } \\
\rho\end{array}$ \\
\hline $\begin{array}{l}\text { Ada Dukungan } \\
\text { Kurang Dukungan } \\
\text { Tidak Ada Dukungan }\end{array}$ & 0.345 & 0.000 \\
\hline Sumber : Data Primer 2016 & & \\
\hline
\end{tabular}

Hasil perhitungan melalui uji statistik dengan menggunakan uji Chi-Square menunjukkan bahwa probabilitas $(\mathrm{p})=$ 0,000 yang berarti $\mathrm{p}<0,05$ artinya Ho ditolak dan $\mathrm{H} 1$ diterima.

Kesimpulannya adalah ada hubungan yang signifikan antara dukungan dari kader posyandu dengan tingkat Kunjungan ibu menimbangkan anaknya ke posyandu. Dukungan dari kader posyandu yang berupa keaktifan kader baik itu pada hari pelaksanaan posyandu.

Pada hari sebelum dan sesudah kegiatan posyandu diaman pada hari sebelum pelaksanaan posyandu kader aktif dalam pemberitahuan pelaksanaan posyandu kepada semua masyarakat yang menjadi sasaran, pada hari pelaksanaan posyandu kader posyandu aktif pada pelaksanaan posyandu setiap bulannya dan pada hari sesudah posyandu para kader hendaknya melakukan kunjungan rumah kepada para ibu bayi/balita sasaran yang tidak datang ke posyandu serta melakukan penyuluhan secara individu.

Selain aktif melaksanakan tugasnya kader posyandu diharapkan semakin terampil melakukan pelayanan kepada ibu 
balita, karena dapat meningkatkan respon para ibu balita untuk datang ke posyandu. Kader posyandu sebaiknya bersikap ramah dan baik dalam melaksanakan tugasnya pada saat hari pelaksanaan posyandu sehingga masyarakat merasa nyaman dan senang datang ke posyandu.
Nilai koefisien korellasi sebesar 0.345 ini menunjukan bahwa dukungan kader terhadap tingkat kehadiran ibu ke posyandu sudah cukup erat artinya makin aktiv kader makin tinggi pula tingkat kehadiran ibu balita membawa anaknya ke posyandu.

Tabel 24. Hubungan Sikap Dukungan Keluarga dengan Tingkat Kunjungan Ibu dalam Penimbangan Balita ke Posyandu di Wilayah Kerja Puskesmas Suradita Kecamatan Cisauk Kabupaten Tangerang Propinsi Banten Tahun 2016.

\begin{tabular}{|c|c|c|c|c|c|c|c|c|}
\hline \multirow{3}{*}{$\begin{array}{c}\text { Sikap } \\
\text { Dukungan Keluarga }\end{array}$} & \multicolumn{6}{|c|}{ Tingkat Kunjungan Ibu Balita ke Posyandu } & \multirow{2}{*}{\multicolumn{2}{|c|}{ Jumlah }} \\
\hline & \multicolumn{2}{|c|}{ Tidak Pernah } & \multicolumn{2}{|c|}{$\begin{array}{l}\leq 8 X \text { dalam } \\
\text { Setahun }\end{array}$} & \multicolumn{2}{|c|}{$\begin{array}{l}\geq 8 \times \text { dalam } \\
\text { Setahun }\end{array}$} & & \\
\hline & $\mathbf{n}$ & $\%$ & $\mathbf{N}$ & $\%$ & $\mathbf{N}$ & $\%$ & $\mathbf{n}$ & $\%$ \\
\hline Ada Dukungan & $\mathbf{0}$ & $\mathbf{0 . 0 0}$ & 3 & 5.50 & 52 & 94.5 & 55 & 100 \\
\hline Kurang Dukungan & $\mathbf{0}$ & 0.00 & 5 & 25.0 & 15 & 75.0 & 20 & 100 \\
\hline $\begin{array}{l}\text { Tidak Ada } \\
\text { Dukungan }\end{array}$ & 5 & 50.0 & 2 & 20.0 & 3 & 30.0 & 10 & 100 \\
\hline Total & 5 & 5.90 & 10 & 11.8 & $\mathbf{7 0}$ & 82.4 & 85 & 100 \\
\hline
\end{tabular}

Sumber : Hasil olah data 2016

Hasil analisis Bivariat menunjukan bahwa ibu yang mendapat dukungan keluarga maupun kurang mendapat dukungan bahkan tidak mendapatkan dukungan dari keluarga $94.5 \%$ dukungan keluarga yang baik para ibu melakukan kunjungan lebih dari 8 kali dalam setahun, yang kurang dukungan $75 \%$ hadir lebih dari delapan kali kunjungan dan $30 \%$ hadir tanpa dukungan keluarga dan lebih dari 8 kali dalam setahun.

Analisis ini dapat menggambarkan bahwa dukungan atau support keluarga sangatlah penting agar ibu dan anak balitanya secara rutin menimbangkan bayinya ke posyandu.

Tabel 25. Hasil Perhitungan nilai koefisien Korellasi dan Nilai Chi square Test Sikap Dukungan Keluarga dengan Tingkat Kunjungan Ibu dalam Penimbangan Balita ke Posyandu di Wilayah Kerja Puskesmas Suradita Kecamatan Cisauk Kabupaten Tangerang Propinsi Banten Tahun 2016

\begin{tabular}{|l|c|c|}
\hline \multirow{2}{*}{ Sikap Dukungan Keluarga } & \multicolumn{2}{|c|}{$\begin{array}{c}\text { Tingkat Kunjungan Ibu Balita ke } \\
\text { Posyandu }\end{array}$} \\
\cline { 2 - 3 } & $\begin{array}{c}\text { Nilai Koefisien Korelasi } \\
(\mathbf{r})\end{array}$ & $\begin{array}{c}\text { Nilai } \\
\rho\end{array}$ \\
\hline Ada Dukungan & \multirow{2}{*}{$\mathbf{0 . 6 0 7}$} & 0.000 \\
\hline Kurang Dukungan & & \\
\hline Tidak Ada Dukungan & & \\
\hline
\end{tabular}

\section{Sumber : Data Primer 2016}

Hasil uji stastistik dengan menggunakan uji Chi-Square menunjukkan bahwa probabilitas $(p)=0,000$ yang berarti $\mathrm{p}<0,05$ artinya Ho ditolak dan H1 diterima.Kesimpulannya adalah ada hubungan yang signifikan antara dukungan dari keluarga responden dengan tingkat Kunjungan ibu menimbangkan anaknya ke posyandu, besaran koefisien korellasi sebesar 0.607 ini menunjukan bahwa dukungan keluarga sangatlah erat kaitannya, artinya semakin bagus dukungan keluarga maka tingkat kunjungan ibu ke posyandu pun akan semakin kuat dan meningkat. 
Dalam beberapa wawancara terbuka dengan para ibu Di Posyandu wilayah kerja Puskesmas Suradita kecamatan Cisauk Kabupaten Tangerang Tahun 2016 ternaya masih banyak ibu mengaku tidak pernah diingatkan keluarga pada saat jadwal hari buka posyandu tiap bulannya dan tidak pernah diinformasikan bahwa penting membawa balita untuk ditimbang sehinga terpantau pertumbuhan dan perkembangan balitanya dari keluarga khususnya kepala keluarga,

Sehingga kondisi ini terkadang ibu sendiri juga lupa dan menganggap atau ada anggapan juga bahwa kegiatan penimbangan balita rutin setiap bulan bukan hal yang penting untuk membawa balita ke posyandu pada hari buka posyandu kondisi ini terjadi karena keluarga khususnya suami yang banting tulang bekerja sehingga setidaknya inisiatif istri bisa lebih baik manakala suami lupa mengingatkan atau mengantar buah hati dan istrinya ke posyandu.

Hal ini disebabkan karena kurangnya perhatian dari pihak keluarga khususnya kepala keluarga, ini merupakan suatu masalah dalam pemantauan pertumbuhan dan perkembangan bayi dan balita, masalah ini perlu diselesaikan dengan segera, dalam hal ini perlu dukungan dari tokoh masyarakat,tokoh agama dan tokoh lainnya khususnya kepala lingkungan dan petugas kesehatan agar dapat secara proaktif memberikan penyuluhan secara individu kepada keluarga tersebut.

\section{Analisis Multivariat.}

Analisis multivariat dilakukan Setelah dilakukannya analisis univariat, dan analisis bivariat selesai. Langkah selanjutnaya adalah factor yang sudah ditemukan akan dianalisa kembali seperti berikut ini:

Tabel 26. Rekapitulasi Hasil Analisis Bivariat Faktor-faktor yang berhubungan dengan Tingkat Kunjungan Ibu dalam Penimbangan Balita ke Posyandu di Wilayah Kerja

Puskesmas Suradita Kecamatan Cisauk Kabupaten Tangerang Propinsi Banten Tahun

2016.

\begin{tabular}{|c|c|c|c|c|c|}
\hline No & $\begin{array}{l}\text { Analisis } \\
\text { Variabel }\end{array}$ & Hipotesis & $\begin{array}{l}\text { Nilai Koefisien } \\
\text { Korelasi } \\
(\mathbf{r})\end{array}$ & $\begin{array}{c}\text { Nilai } \\
\rho\end{array}$ & Keterangan \\
\hline 1 & $\begin{array}{l}\text { Hubungan } \\
\text { Tingkat } \\
\text { Keikutsertaan } \\
\text { Pelatihan ibu } \\
\text { balita terhadap } \\
\text { Tingkat } \\
\text { kunjungan Ibu } \\
\text { dalam } \\
\text { Penimbangan } \\
\text { Balita ke } \\
\text { Posyandu di } \\
\text { Wilayah Kerja } \\
\text { Puskesmas } \\
\text { Suradita } \\
\text { Kecamatan } \\
\text { Cisauk } \\
\text { Kabupaten } \\
\text { Tangerang } \\
\text { Propinsi Banten } \\
\text { Tahun 2016. }\end{array}$ & $\begin{array}{l}\mathrm{P}>\alpha 0.05 \\
\mathrm{H} 0 \text { diterima } \\
\text { dan } \mathrm{H} 1 \\
\text { ditolak }\end{array}$ & 0.288 & 0.185 & $\begin{array}{l}\text { Hasil uji stastistik } \\
\text { dengan } \\
\text { menggunakan uji } \\
\text { Chi-Square } \\
\text { menunjukkan } \\
\text { bahwa probabilitas } \\
\text { (p) =0,185 yang } \\
\text { berarti p > a } 0,05 \\
\text { artinya Ho } \\
\text { diterima dan H1 } \\
\text { ditolak, nilai } \\
\text { korelasi } \\
\text { menunjukan nilai } \\
\text { yang lemah }\end{array}$ \\
\hline 2 & $\begin{array}{l}\text { Hubungan } \\
\text { Status ibu balita } \\
\text { terhadap }\end{array}$ & $\mathrm{P}>0.05$ & 0.177 & 0.560 & $\begin{array}{l}\text { Hasil uji stastistik } \\
\text { dengan } \\
\text { menggunakan uji }\end{array}$ \\
\hline
\end{tabular}




\begin{tabular}{|c|c|c|c|c|c|}
\hline & $\begin{array}{l}\text { Tingkat } \\
\text { kunjungan Ibu } \\
\text { dalam } \\
\text { Penimbangan } \\
\text { Balita ke } \\
\text { Posyandu di } \\
\text { Wilayah Kerja } \\
\text { Puskesmas } \\
\text { Suradita } \\
\text { Kecamatan } \\
\text { Cisauk } \\
\text { Kabupaten } \\
\text { Tangerang } \\
\text { Propinsi Banten } \\
\text { Tahun 2016. }\end{array}$ & $\begin{array}{l}\text { H0 diterima } \\
\text { dan H1 } \\
\text { ditolak }\end{array}$ & & & $\begin{array}{l}\text { Chi-Square } \\
\text { menunjukkan } \\
\text { bahwa probabilitas } \\
\text { (p) }=0,560 \text { yang } \\
\text { berarti p > a } 0,05 \\
\text { artinya Ho } \\
\text { diterima dan } \mathrm{H} 1 \\
\text { ditolak, nilai } \\
\text { korellasi } \\
\text { menunjukan nilai } \\
\text { yang lemah. }\end{array}$ \\
\hline 3. & $\begin{array}{l}\text { Hubungan } \\
\text { Jumlah } \\
\text { Tanggungan } \\
\text { terhadap } \\
\text { Tingkat } \\
\text { kunjungan Ibu } \\
\text { dalam } \\
\text { Penimbangan } \\
\text { Balita ke } \\
\text { Posyandu di } \\
\text { Wilayah Kerja } \\
\text { Puskesmas } \\
\text { Suradita } \\
\text { Kecamatan } \\
\text { Cisauk } \\
\text { Kabupaten } \\
\text { Tangerang } \\
\text { Propinsi Banten } \\
\text { Tahun 2016. }\end{array}$ & $\begin{array}{l}\mathrm{P}>0.05 \\
\mathrm{H} 0 \text { diterima } \\
\text { dan } \mathrm{H} 1 \\
\text { ditolak }\end{array}$ & 0.309 & 0.016 & $\begin{array}{l}\text { Hasil uji stastistik } \\
\text { dengan } \\
\text { menggunakan uji } \\
\text { Chi-Square } \\
\text { menunjukkan } \\
\text { bahwa probabilitas } \\
\text { (p) }=0,016 \text { yang } \\
\text { berarti } \mathrm{p}<\text { a } 0,05 \\
\text { artinya Ho ditolak } \\
\text { dan H1 diterima, } \\
\text { nilai korelasi } \\
\text { menunjukan nilai } \\
\text { yang cukup }\end{array}$ \\
\hline 4. & $\begin{array}{l}\text { Hubungan Suku } \\
\text { Bangsa terhadap } \\
\text { Tingkat } \\
\text { kunjungan Ibu } \\
\text { dalam } \\
\text { Penimbangan } \\
\text { Balita ke } \\
\text { Posyandu di } \\
\text { Wilayah Kerja } \\
\text { Puskesmas } \\
\text { Suradita } \\
\text { Kecamatan } \\
\text { Cisauk } \\
\text { Kabupaten } \\
\text { Tangerang } \\
\text { Propinsi Banten } \\
\text { Tahun 2016. }\end{array}$ & $\begin{array}{l}\mathrm{P}>0.05 \\
\mathrm{H} 0 \text { diterima } \\
\text { dan } \mathrm{H} 1 \\
\text { ditolak }\end{array}$ & 0.051 & 0.397 & $\begin{array}{l}\text { Hasil uji stastistik } \\
\text { dengan } \\
\text { menggunakan uji } \\
\text { Chi-Square } \\
\text { menunjukkan } \\
\text { bahwa probabilitas } \\
\text { (p)=0,397 yang } \\
\text { berarti p > a } 0,05 \\
\text { artinya Ho } \\
\text { diterima dan H1 } \\
\text { ditolak, nilai } \\
\text { korelasi } \\
\text { menunjukan nilai } \\
\text { yang lemah }\end{array}$ \\
\hline
\end{tabular}




\begin{tabular}{|c|c|c|c|c|c|}
\hline 5 & $\begin{array}{l}\text { Hubungan } \\
\text { Agama Yang } \\
\text { dianut Ibu Balita } \\
\text { terhadap Tingkat } \\
\text { kunjungan Ibu } \\
\text { dalam } \\
\text { Penimbangan } \\
\text { Balita ke } \\
\text { Posyandu di } \\
\text { Wilayah Kerja } \\
\text { Puskesmas } \\
\text { Suradita } \\
\text { Kecamatan } \\
\text { Cisauk } \\
\text { Kabupaten } \\
\text { Tangerang } \\
\text { Propinsi Banten } \\
\text { Tahun 2016 }\end{array}$ & $\begin{array}{l}\mathrm{P}>0.05 \\
\mathrm{H} 0 \text { diterima } \\
\text { dan } \mathrm{H} 1 \\
\text { ditolak }\end{array}$ & $\mathbf{0 . 1 5 0}$ & 0.804 & $\begin{array}{l}\text { Hasil uji stastistik } \\
\text { dengan } \\
\text { menggunakan uji } \\
\text { Chi-Square } \\
\text { menunjukkan } \\
\text { bahwa probabilitas } \\
\text { (p) }=0,804 \text { yang } \\
\text { berarti p > a } 0,05 \\
\text { artinya Ho } \\
\text { diterima dan H1 } \\
\text { ditolak, nilai } \\
\text { korelasi } \\
\text { menunjukan nilai } \\
\text { yang lemah }\end{array}$ \\
\hline 6 & $\begin{array}{l}\text { Hubungan } \\
\text { Tingkat } \\
\text { Pendidikan Ibu } \\
\text { dengan Tingkat } \\
\text { kunjungan Ibu } \\
\text { dalam } \\
\text { Penimbangan } \\
\text { Balita ke } \\
\text { Posyandu di } \\
\text { Wilayah Kerja } \\
\text { Puskesmas } \\
\text { Suradita } \\
\text { Kecamatan } \\
\text { Cisauk } \\
\text { Kabupaten } \\
\text { Tangerang } \\
\text { Propinsi Banten } \\
\text { Tahun 2016 }\end{array}$ & $\begin{array}{l}\mathrm{P}>0.05 \\
\mathrm{H} 0 \text { diterima } \\
\text { dan } \mathrm{H} 1 \\
\text { ditolak }\end{array}$ & 0.463 & $\mathbf{0 . 0 0 0}$ & $\begin{array}{l}\text { Hasil uji stastistik } \\
\text { dengan } \\
\text { menggunakan uji } \\
\text { Chi-Square } \\
\text { menunjukkan } \\
\text { bahwa probabilitas } \\
\text { (p) }=0,000 \text { yang } \\
\text { berarti } \mathrm{p}<\text { a } 0,05 \\
\text { artinya Ho ditolak } \\
\text { dan H1 diterima, } \\
\text { nilai korelasi } \\
\text { menunjukan nilai } \\
\text { yang cukup kuat. }\end{array}$ \\
\hline 7 & $\begin{array}{l}\text { Hubungan } \\
\text { Pekerjaan Ibu } \\
\text { dengan Tingkat } \\
\text { Kunjungan Ibu } \\
\text { dalam } \\
\text { Penimbangan } \\
\text { Balita ke } \\
\text { Posyandu di } \\
\text { Wilayah Kerja } \\
\text { Puskesmas } \\
\text { Suradita } \\
\text { Kecamatan } \\
\text { Cisauk } \\
\text { Kabupaten } \\
\text { Tangerang } \\
\text { Propinsi Banten } \\
\text { Tahun 2016 }\end{array}$ & $\begin{array}{l}\mathrm{P}>0.05 \\
\mathrm{H} 0 \text { diterima } \\
\text { dan } \mathrm{H} 1 \\
\text { ditolak }\end{array}$ & 0.110 & 0.000 & $\begin{array}{l}\text { Hasil uji stastistik } \\
\text { dengan } \\
\text { menggunakan uji } \\
\text { Chi-Square } \\
\text { menunjukkan } \\
\text { bahwa probabilitas } \\
\text { (p) }=0,000 \text { yang } \\
\text { berarti p < a } 0,05 \\
\text { artinya Ho ditolak } \\
\text { dan H1 diterima, } \\
\text { nilai korelasi } \\
\text { menunjukan nilai } \\
\text { yang cukup kuat. }\end{array}$ \\
\hline
\end{tabular}




\begin{tabular}{|c|c|c|c|c|c|}
\hline 8 & $\begin{array}{l}\text { Hubungan } \\
\text { Pengetahuan } \\
\text { Ibu dengan } \\
\text { Tingkat } \\
\text { Kunjungan Ibu } \\
\text { dalam } \\
\text { Penimbangan } \\
\text { Balita ke } \\
\text { Posyandu di } \\
\text { Wilayah Kerja } \\
\text { Puskesmas } \\
\text { Suradita } \\
\text { Kecamatan } \\
\text { Cisauk } \\
\text { Kabupaten } \\
\text { Tangerang } \\
\text { Propinsi Banten } \\
\text { Tahun 2016. }\end{array}$ & $\begin{array}{l}\mathrm{P}>0.05 \\
\mathrm{H} 0 \text { diterima } \\
\text { dan } \mathrm{H} 1 \\
\text { ditolak }\end{array}$ & 0.359 & 0.004 & $\begin{array}{l}\text { Hasil uji stastistik } \\
\text { dengan } \\
\text { menggunakan uji } \\
\text { Chi-Square } \\
\text { menunjukkan } \\
\text { bahwa probabilitas } \\
\text { (p) }=0,000 \text { yang } \\
\text { berarti p < a } 0,05 \\
\text { artinya Ho ditolak } \\
\text { dan H1 diterima, } \\
\text { nilai korelasi } \\
\text { menunjukan nilai } \\
\text { yang cukup kuat. }\end{array}$ \\
\hline 9 & $\begin{array}{l}\text { Hubungan Sikap } \\
\text { Ibu dengan } \\
\text { Tingkat } \\
\text { Kunjungan Ibu } \\
\text { dalam } \\
\text { Penimbangan } \\
\text { Balita ke } \\
\text { Posyandu di } \\
\text { Wilayah Kerja } \\
\text { Puskesmas } \\
\text { Suradita } \\
\text { Kecamatan } \\
\text { Cisauk } \\
\text { Kabupaten } \\
\text { Tangerang } \\
\text { Propinsi Banten } \\
\text { Tahun 2016. }\end{array}$ & $\begin{array}{l}\mathrm{P}>0.05 \\
\mathrm{H} 0 \text { diterima } \\
\text { dan } \mathrm{H} 1 \\
\text { ditolak }\end{array}$ & 0.549 & 0.000 & $\begin{array}{l}\text { Hasil uji stastistik } \\
\text { dengan } \\
\text { menggunakan uji } \\
\text { Chi-Square } \\
\text { menunjukkan } \\
\text { bahwa probabilitas } \\
\text { (p) }=0,000 \text { yang } \\
\text { berarti p < a 0,05 } \\
\text { artinya Ho ditolak } \\
\text { dan H1 diterima, } \\
\text { nilai korelasi } \\
\text { menunjukan nilai } \\
\text { yang cukup kuat. }\end{array}$ \\
\hline $\mathbf{1 0}$ & $\begin{array}{l}\text { Hubungan } \\
\text { Kehadiran Kader } \\
\text { Posyandu } \\
\text { dengan Tingkat } \\
\text { Kunjungan Ibu } \\
\text { dalam } \\
\text { Penimbangan } \\
\text { Balita ke } \\
\text { Posyandu di } \\
\text { Wilayah Kerja } \\
\text { Puskesmas } \\
\text { Suradita } \\
\text { Kecamatan } \\
\text { Cisauk } \\
\text { Kabupaten } \\
\text { Tangerang } \\
\text { Propinsi Banten } \\
\text { Tahun 2016 }\end{array}$ & $\begin{array}{l}\mathrm{P}>0.05 \\
\mathrm{H} 0 \text { diterima } \\
\text { dan } \mathrm{H} 1 \\
\text { ditolak }\end{array}$ & 0.062 & 0.001 & $\begin{array}{l}\text { Hasil uji stastistik } \\
\text { dengan } \\
\text { menggunakan uji } \\
\text { Chi-Square } \\
\text { menunjukkan } \\
\text { bahwa probabilitas } \\
\text { (p) }=0,001 \text { yang } \\
\text { berarti p < a 0,05 } \\
\text { artinya Ho ditolak } \\
\text { dan H1 diterima, } \\
\text { nilai korelasi } \\
\text { menunjukan nilai } \\
\text { yang cukup kuat. }\end{array}$ \\
\hline
\end{tabular}




\begin{tabular}{|c|c|c|c|c|c|}
\hline 11 & $\begin{array}{l}\text { Hubungan } \\
\text { Kelengkapan } \\
\text { Peralatan dan } \\
\text { Sarana Posyandu } \\
\text { dengan Tingkat } \\
\text { Kunjungan Ibu } \\
\text { dalam } \\
\text { Penimbangan } \\
\text { Balita ke } \\
\text { Posyandu di } \\
\text { Wilayah Kerja } \\
\text { Puskesmas } \\
\text { Suradita } \\
\text { Kecamatan } \\
\text { Cisauk } \\
\text { Kabupaten } \\
\text { Tangerang } \\
\text { Propinsi Banten } \\
\text { Tahun 2016 }\end{array}$ & $\begin{array}{l}\mathrm{P}>0.05 \\
\mathrm{H} 0 \text { diterima } \\
\text { dan } \mathrm{H} 1 \\
\text { ditolak }\end{array}$ & 0.474 & 0.000 & $\begin{array}{l}\text { Hasil uji stastistik } \\
\text { dengan } \\
\text { menggunakan uji } \\
\text { Chi-Square } \\
\text { menunjukkan } \\
\text { bahwa probabilitas } \\
\text { (p) }=0,000 \text { yang } \\
\text { berarti } \mathrm{p}<\text { a } 0,05 \\
\text { artinya Ho ditolak } \\
\text { dan H1 diterima, } \\
\text { nilai korelasi } \\
\text { menunjukan nilai } \\
\text { yang cukup kuat. }\end{array}$ \\
\hline 12 & $\begin{array}{l}\text { Hubungan Jarak } \\
\text { Rumah Ke } \\
\text { Posyandu } \\
\text { dengan Tingkat } \\
\text { Kunjungan Ibu } \\
\text { dalam } \\
\text { Penimbangan } \\
\text { Balita ke } \\
\text { Posyandu di } \\
\text { Wilayah Kerja } \\
\text { Puskesmas } \\
\text { Suradita } \\
\text { Kecamatan } \\
\text { Cisauk } \\
\text { Kabupaten } \\
\text { Tangerang } \\
\text { Propinsi Banten } \\
\text { Tahun 2016 }\end{array}$ & $\begin{array}{l}\mathrm{P}>\text { a } 0.05 \\
\mathrm{H} 0 \text { diterima } \\
\text { dan } \mathrm{H} 1 \\
\text { ditolak }\end{array}$ & 0.065 & 0.000 & $\begin{array}{l}\text { Hasil uji stastistik } \\
\text { dengan } \\
\text { menggunakan uji } \\
\text { Chi-Square } \\
\text { menunjukkan } \\
\text { bahwa probabilitas } \\
\text { (p) }=0,000 \text { yang } \\
\text { berarti p < a } 0,05 \\
\text { artinya Ho ditolak } \\
\text { dan H1 diterima, } \\
\text { nilai korelasi } \\
\text { menunjukan nilai } \\
\text { yang lemah. }\end{array}$ \\
\hline 13 & $\begin{array}{l}\text { Hubungan Sikap } \\
\text { Dukungan Kader } \\
\text { Posyandu } \\
\text { dengan Tingkat } \\
\text { Kunjungan Ibu } \\
\text { dalam } \\
\text { Penimbangan } \\
\text { Balita ke } \\
\text { Posyandu di } \\
\text { Wilayah Kerja } \\
\text { Puskesmas } \\
\text { Suradita } \\
\text { Kecamatan } \\
\text { Cisauk } \\
\text { Kabupaten } \\
\text { Tangerang } \\
\text { Propinsi Banten } \\
\text { Tahun 2016 }\end{array}$ & $\begin{array}{l}\mathrm{P}>0.05 \\
\mathrm{H} 0 \text { diterima } \\
\text { dan } \mathrm{H} 1 \\
\text { ditolak }\end{array}$ & 0.345 & 0.000 & $\begin{array}{l}\text { Hasil uji stastistik } \\
\text { dengan } \\
\text { menggunakan uji } \\
\text { Chi-Square } \\
\text { menunjukkan } \\
\text { bahwa probabilitas } \\
\text { (p) = } 0,000 \text { yang } \\
\text { berarti } \mathrm{p} \text { < a } 0,05 \\
\text { artinya Ho ditolak } \\
\text { dan H1 diterima, } \\
\text { nilai korelasi } \\
\text { menunjukan nilai } \\
\text { yang cukup kuat. }\end{array}$ \\
\hline
\end{tabular}




\begin{tabular}{|c|c|c|c|c|c|}
\hline 14 & $\begin{array}{l}\text { Hubungan Sikap } \\
\text { Dukungan } \\
\text { Keluarga dengan } \\
\text { Tingkat } \\
\text { Kunjungan Ibu } \\
\text { dalam } \\
\text { Penimbangan } \\
\text { Balita ke } \\
\text { Posyandu di } \\
\text { Wilayah Kerja } \\
\text { Puskesmas } \\
\text { Suradita } \\
\text { Kecamatan } \\
\text { Cisauk } \\
\text { Kabupaten } \\
\text { Tangerang } \\
\text { Propinsi Banten } \\
\text { Tahun 2016 }\end{array}$ & $\begin{array}{l}\mathrm{P}>0.05 \\
\mathrm{H} 0 \text { diterima } \\
\text { dan } \mathrm{H} 1 \\
\text { ditolak }\end{array}$ & 0.607 & 0.000 & $\begin{array}{l}\text { Hasil uji stastistik } \\
\text { dengan } \\
\text { menggunakan uji } \\
\text { Chi-Square } \\
\text { menunjukkan } \\
\text { bahwa probabilitas } \\
\text { (p) =0,000 yang } \\
\text { berarti p < a } 0,05 \\
\text { artinya Ho ditolak } \\
\text { dan H1 diterima, } \\
\text { nilai korelasi } \\
\text { menunjukan nilai } \\
\text { yang cukup kuat. }\end{array}$ \\
\hline
\end{tabular}

\section{Sumber : Hasil olah data 2016}

Dari tabel diatas terlihat factor yang secara signifikan mempengaruhi atau ada hubungan dengan tingkat Kunjungan Ibu dalam Penimbangan Balita ke Posyandu di Wilayah Kerja Puskesmas Suradita Kecamatan Cisauk Kabupaten Tangerang Propinsi Banten Tahun 2016 nilai $\mathrm{p}<0.05$ adalah sebagai berikut :

1) Tingkat Pendidikan

2) Pekerjaan ibu

3) Jumlah tanggungan ibu

4) Pengetahuan ibu akan Posyandu

5) Sikap Ibu pada kegiatan Posyandu

6) Tingkat Kehadiran Kader

7) Kelengkapan sarana dan peralatan di Posyandu

Tabel 27 Rekapitulasi Efek Langsung,efek tidak langsung dan efek total. Faktor-faktor yang berhubungan dengan Tingkat Kunjungan Ibu dalam Penimbangan Balita ke Posyandu di Wilayah Kerja Puskesmas Suradita Kecamatan Cisauk Kabupaten Tangerang Propinsi Banten Tahun 2016.

\begin{tabular}{|c|l|c|c|c|}
\hline No & \multicolumn{1}{|c|}{ Variabel } & Efek Langsung & $\begin{array}{c}\text { Efek tidak } \\
\text { langsung }\end{array}$ & Total Efek \\
\hline $\mathbf{1}$ & $\begin{array}{l}\text { Tingkat Pendidikan } \\
\text { dengan Tingkat } \\
\text { Kunjungan ibu } \\
\text { balita ke posyandu }\end{array}$ & -0.130 & 0.000 & -0.212 \\
\hline $\mathbf{2}$ & $\begin{array}{l}\text { Pekerjaan ibu } \\
\text { dengan Tingkat } \\
\text { Kunjungan ibu } \\
\text { balita ke posyandu }\end{array}$ & $\mathbf{0 . 0 8 9}$ & 0.000 & $\mathbf{0 . 1 5 6}$ \\
\hline $\mathbf{3}$ & $\begin{array}{l}\text { Pengetahuan Ibu } \\
\text { dengan Tingkat }\end{array}$ & -0.010 & 0.000 & -0.016 \\
\hline
\end{tabular}

8) Jarak / Lokasi Posyandu

9) Dukungan Kader

10) Dukungan Keluarga

Sedangkan factor yang secara signifikan tidak mempengaruhi atau tidak ada hubungan dengan tingkat Kunjungan Ibu dalam Penimbangan Balita ke Posyandu di Wilayah Kerja Puskesmas Suradita Kecamatan Cisauk Kabupaten Tangerang Propinsi Banten Tahun 2016 nilai $\mathrm{p}>0.05$ adalah sebagai berikut :

1) Keikut sertaan ibu dalam pelatihan

2) Status ibu balita

3) Suku Bangsa

4) Agama yang dianut 


\begin{tabular}{|c|c|c|c|c|}
\hline & $\begin{array}{l}\text { Kunjungan ibu } \\
\text { balita ke posyandu }\end{array}$ & & & \\
\hline 4 & $\begin{array}{l}\text { Sikap ibu dengan } \\
\text { Tingkat Kunjungan } \\
\text { ibu balita ke } \\
\text { posyandu }\end{array}$ & 0.228 & 0.000 & 0.302 \\
\hline 5 & $\begin{array}{l}\text { Kehadiran Kader } \\
\text { dengan Tingkat } \\
\text { Kunjungan ibu } \\
\text { balita ke posyandu }\end{array}$ & 0.040 & 0.000 & 0.065 \\
\hline 6 & $\begin{array}{l}\text { Kelengkapan } \\
\text { Sarana dan } \\
\text { peralatan posyandu } \\
\text { dengan Tingkat } \\
\text { Kunjungan ibu } \\
\text { balita ke posyandu }\end{array}$ & -0.127 & 0.000 & -0.115 \\
\hline 7 & $\begin{array}{l}\text { Jarak/lokasi } \\
\text { Posyandu dengan } \\
\text { Tingkat Kunjungan } \\
\text { ibu balita ke } \\
\text { posyandu }\end{array}$ & -0.031 & 0.000 & -0.053 \\
\hline 8 & $\begin{array}{l}\text { Dukungan Kader } \\
\text { Posyandu dengan } \\
\text { Tingkat Kunjungan } \\
\text { ibu balita ke } \\
\text { posyandu }\end{array}$ & 0.016 & 0.000 & $\mathbf{0 . 0 2 0}$ \\
\hline 9 & $\begin{array}{l}\text { Dukungan } \\
\text { Keluarga dengan } \\
\text { Tingkat Kunjungan } \\
\text { ibu balita ke } \\
\text { posyandu }\end{array}$ & 0.338 & 0.000 & 0.498 \\
\hline 10 & $\begin{array}{l}\text { Jumlah } \\
\text { Tanggungan } \\
\text { Keluarga dengan } \\
\text { tingkat kunjungan }\end{array}$ & 0.154 & 0.000 & 0.190 \\
\hline
\end{tabular}

\section{Sumber : Hasil olah data 2016}

Dari hasil perhitungan diatas ditemukan bahwa yang dominan mempengaruhi tingkat kehadiran ibu di posyandu adalah Jumlah tanggungan keluarga,Dukungan keluarga, sikap ibu,dukungan kader posyandu,pekerjaan ibu dan kehadiran kader posyandu dari keenam factor tersebut ada tiga yang secara positip dominan memengaruhi atau berhubungan dengan tingkat kunjungan ibu ke posyandu yaitu Dukungan Keluarga, sikap ibu dan Jumlah Tanggungan ibu.

\section{KESIMPULAN}

1. Dari hasil analisis sampel tingkat penimbangan balita ke posyandu di Wilayah Kerja Puskesmas Suradita Kecamatan Cisauk Kabupaten Tangerang Propinsi Banten Tahun 2016. $5.9 \%$ tidak pernah ke posyandu $11.8 \%$ kurang dari 8 kali dalam setahun dan $82.4 \%$ lebih dari 8 kali dalam setahun mengunjungi posyandu. Dari data diatas dapat dikatakan bahwa tingkat kunjungan ibu balita dalam penimbangan balita ke posyandu relative sudah tinggi.

2. Tidak semua faktor yang diduga berhubungan atau berkaitan terbukti secara signifikan berhubungan dengan tingkat Kunjungan ibu dalam 
penimbangan balita ke posyandu. Faktor yang terbukti secara positip dan signifikan ada hubungan dengan tingkat Kunjungan ibu dalam penimbangan balita ke posyandu adalah jumlah tanggungan keluarga $\mathrm{r}$ ( 0.309) dan $\mathrm{p}$ (0.016), Tingkat Pendidikan ibu $r$ (0.463) dan $\mathrm{p}$ (0.000), Pekerjaan ibu $\mathrm{r}$ (0.110) dan $\mathrm{p}$ (0.000), Pengetahuan ibu akan Posyandu $r$ (0.359) dan $p$ (0.004),Sikap Ibu pada kegiatan Posyandu r (0.549) dan p (0.000), Tingkat Kehadiran Kader posyandu $r \quad(0.062)$ dan $r$ (0.001),Kelengkapan sarana dan peralatan di Posyandu r (0.474) dan $\mathrm{p}$ (0.000),Jarak / Lokasi Posyandu $\mathrm{r}$ (0.065) dan p (0.000),Dukungan Kader $r$ (0.345) dan $\mathrm{p}(0.000)$ dan Dukungan Keluarga r (0.607) dan p (0.000).

3. Sedangkan factor yang secara signifikan tidak mempengaruhi atau tidak ada hubungan dengan tingkat Kunjungan Ibu dalam Penimbangan Balita ke Posyandu di Wilayah Kerja Puskesmas Suradita Kecamatan Cisauk Kabupaten Tangerang Propinsi Banten Tahun 2016 nilai $\mathrm{p}>0.05$ adalah sebagai berikut :Keikut sertaan ibu dalam pelatihan $r$ (0.228) dan $\mathrm{p}$ (0.185),Status ibu balita $r$ (0.177) dan $p$ (0.560),Suku Bangsa $r$ (0.051) dan p (0.397) dan Agama yang dianut $r(0.150)$ dan $p(0.804)$.

4. Faktor dominan berefek langsung dengan tingkat kehadiran ibu di posyandu adalah,Dukungan keluarga 0.338. sikap ibu pada posyandu 0.228,Jumlah tanggungan keluarga 0.154 , pekerjaan ibu 0.089 ,kehadiran kader posyandu 0.040 dan dukunngan kader posyandu sebesar 0.016 .

5. Dilihat dari besaran efek baik langsung maupun tidak langsung ternyata yang paling berefek besar dan bernilai positip atas Tingkat Kunjungan Ibu dalam Penimbangan Balita ke Posyandu di Wilayah Kerja Puskesmas Suradita Kecamatan Cisauk Kabupaten Tangerang Propinsi Banten Tahun 2016 adalah Dukungan Keluarga, 0.498,
Sikap Ibu 0.302,Jumlah tanggungan 0.190, dan Pekerjaan ibu 0.156.

\section{SARAN}

1. Kepada Kepala Lingkungan pemerintahan dan Kader Posyandu alangkah bagusnya untuk dapat melengkapi seluruh peralatan posyandu misalnya saja alat pengukur tinggi badan/microtoise/pita sentimeter yang biasa digunakan untuk melihat pertumbuhan dan status gizi anak bayi dan balita dan membagusi gedung posyandu agar lebih memadai dan nyaman dalam rangka merefitalisasi kembali fungsi posyandu di masyarakat.

2. Kepada Kepala Lingkungan dan Kader posyandu seyogyanya mampu untuk bekerja sama dengan berbagai pihak khususnya tokoh masyarakat, ibu-ibu PKK yang dilakukan secara terus menerus dan dapat mengkoordinasikan penggerakan masyarakat untuk dapat hadir pada hari buka posyandu.

3. Kepada petugas kesehatan supaya lebih meningkatkan peran serta masyarakat dan kinerja kader posyandu dalam kegiatan posyandu dengan tujuan untuk lebih meningkatkan kemampuan penggerakan kesehatan berbasis masyarakat.

4. Sepertinya Perlu adanya data-data yang dihasilkan dari kegiatan penelitian yang bersifat kualitatif yang dapat menggali lebih mendalam faktorfaktor lain yang berhubungan dengan tingkat Kunjungan ibu dalam penimbangan balita di wilayah kerja Puskesmas Suradita Kecamatan Cisauk Kabupaten Tangerang Tahun 2016.

5. Dari Hasil Penelitian diketahui faktor yang paling dominan mempengaruhi atau berhubungan dengan tingkat kehadiran ibu di posyandu adalah Jumlah tanggungan keluarga, Dukungan keluarga, sikap ibu,dukungan kader posyandu, pekerjaan ibu dan kehadiran kader 
posyandu dan jika Dilihat dari besaran efek baik langsung maupun tidak langsung ternyata yang paling berefek besar atas Tingkat Kunjungan Ibu dalam Penimbangan Balita ke Posyandu di Wilayah Kerja Puskesmas Suradita Kecamatan Cisauk Kabupaten Tangerang Propinsi Banten Tahun 2016 adalah Jumlah tanggungan keluarga,Dukungan Keluarga,Sikap Ibu dan Pekerjaan ibu. Maka dari itu perlu adanya sinergi antar keluarga untuk dapat saling mengingatkan pergi ke posyandu,sikap ibu yang positip dan pekerjaan ibu dan jumlah tanggungan keluarga dapat lebih disesuaikan agar dapat ikut kegiatan posyandu khususnya kegiatan penimbangan balita.

\section{DAFTAR PUSTAKA}

Green L. Health Education Planning, A Diagnostic Approuch. . .The John Hopkins University: Mayfield Publishing Co; (1990)

Depkes RI. 2006. Pedoman Umum Pengelolaan Posyandu, Jakarta.

Kementrian Kesehatan Republik Indonesia, 2007. http://www.depkes.go.id /index.php/berita/pressrelease/848menkesresmikan-rumahpemulihangizibalita.html

Peraturan Mentri Kesehatan RI Nomor 741/Menkes/PER/VII/2 008 Tentang Standar Pelayanan Minimal (SPM) Bidang Kesehatan Di Kabupaten/Kota, Jakarta. http://www.depkes.go.id/ downloads/SKSPM.pdf

Kemenkes RI. Buku Panduan Kader Posyandu Menuju Keluarga Sadar Gizi. Jakarta Direktorat Bina Gizi Kementerian Kesehatan R.I; (2011) Departemen kesesehatan RI, 2011.

Pedoman Umum pengelolaan Posyandu. Jakarta: Departemen Kesehatan RI dan Kelompok Kerja OPERASIONAL POSYANDU,
Notoatmodjo, 2005. Metodologi Penelitian Kesehatan. Jakarta: Rineke Cipta.

Profil Kesehatan Kabupaten Tangerang 2010, Dinas Kesehatan Kabupaten Tangerang 2010

Profil Kesehatan Provinsi Banten Tahun 2011, Dinas Kesehatan Propinsi Banten 2011

Kholid A. Promosi Kesehatan dengan Pendekatan Teori Perilaku, Media, dan Aplikasinya. Jakarta: Raja Grafindo Persada; (2012.).

S. Hindu Mathi1, Heru Santosa2, Maya Fitria2, Faktor - Faktor Yang Berhubungan Dengan Tingkat Partisipasi Ibu Dalam Penimbangan Balita Ke Posyandu Di Wilayah Kerja Puskesmas Darussalam Kecamatan Medan Petisah Tahun 2013,USU,2013

Lely Toad1, Sesca D. Solang2, Linda A. Makalew,Faktor-Faktor Yang Berhubungan Dengan Kunjungan Balita Di Posyandu Kelurahan Karondoran Kecamatan Ranowulu Kota Bitung,Jurnal Ilmiah Bidan 2013

Profil Kesehatan Kabupaten Tangerang 2015, Dinas Kesehatan Kabupaten Tangerang 2015, Jurusan Gizi Poltekkes Kemenkes Manado, 2015

Nonce N. Legi1, Fred Rumagit ${ }^{2}$, Ana B. Montol $^{3}$, Riaty Lule, Faktor Yang Berhubungan Dengan Keaktifan Kader Posyandu Di Wilayah Kerja Puskesmas Ranotana Weru, Profil Kesehatan Indonesia 2016, Kementrian Kesehatan Republik Indonesia 2016. 